University of Louisville

ThinkIR: The University of Louisville's Institutional Repository

Electronic Theses and Dissertations

1949

\title{
Who is committed to the Louisville Workhouse?
}

\author{
Hurston C. Burkhart
}

University of Louisville

Edward Edward Ellis, 1919-1999

James H. Ewalt, 1919-1972

Louella Mae Jones

Follow this and additional works at: https://ir.library.louisville.edu/etd

Part of the Social Work Commons

\section{Recommended Citation}

Burkhart, Hurston C.; Ellis,, Edward Edward 1919-1999; Ewalt, James H. 1919-1972; and Jones, Louella Mae, "Who is committed to the Louisville Workhouse?" (1949). Electronic Theses and Dissertations. Paper 1918.

https://doi.org/10.18297/etd/1918

This Master's Thesis is brought to you for free and open access by ThinkIR: The University of Louisville's Institutional Repository. It has been accepted for inclusion in Electronic Theses and Dissertations by an authorized administrator of ThinkIR: The University of Louisville's Institutional Repository. This title appears here courtesy of the author, who has retained all other copyrights. For more information, please contact thinkir@louisville.edu. 


\title{
UNIVERSITY OF LOUISVILLE
}

WHO IS COMMITTED TO THE LOUISVILLE WORKHOUSE?

\author{
A Research Project \\ Submitted to the Faculty \\ of the Raymond A. Kent School of Social Work \\ In Partial Fultiliment of the \\ Requirements for the Degree \\ Ot Master of Science in Social Work
}

\author{
By \\ Hurston C. Burknart \\ Edward E. Ellis \\ James H. Ewalt \\ Louella Mae Jones
}

1949 
NAMES OF STUDENTS: Hurston C. Burkhart

Edward E. Eillis

James $h$. Ewalt

Louella Mae Jones

TITLE OF RESEARCH

PROJECT: WHO IS COMITTED TO THE LOUISVILLE WORKHOUSE?

APPROVED:

HoweIl V. Williams, Dean

DATE: lene 4:948. 


\section{ACKNOWLEDGMENT}

The Project Committee wishes to acknowledge its appreciation for the assistance of Miss Louise Diecks, Director of the Louisville Department of Welfare; also the entire staff of the City Workhouse who gave splendid cooperation. It should not be forgotten that 214 men and women committed to the Workhouse have made this study possible by answering questions about themselves. 
I. HISTORY OF THE WORKHOUSE .......... 1

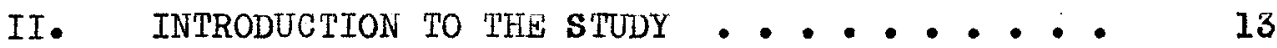

\section{Purpose}

Previous Studies

Scope and Method.

Composition of the sample

Commitment Procedure

III. CURRENT OHFENSE AND PRIOR CRIMINAL RECORD • •

Offense

Length of Sentence

Previous Commitments

Previous Arrests

IV. FAIILY BACKGROUND . . . . . . . .

Nativity of Parents

Type of Community Background

Marital Status

Number of Dependents

V. PERSONAL CHARACTERISTICS ..........

Age

Race and Sex

Obvious Physical Detects

VI. PERSONAL BACKGROUND . . . . . . . . .

Education

Age on Leaving School

Reason f'or Leaving School

Age on Leaving Home

Residence in City

Religion

Military Service 
VII. ECONOMIC BACKGROUND . . . . . . . . •

Means of Support

Trade

Employment status at Time of Arrest

Registrations at Kentucky State

Einployment Service

Social Service Exchange Registrations

VIII. SUMRART AIND CONCLUSIONS . . . . . . . .

Summary

Conclusions

APPEND IXES

Appendix A: Powers and Duties of the Department of Public Weltare, Louisville, Kentucky

B: Letter dated July 30, 1948, from Miss Louise Diecks, Director, Louisville Department of' Welf'are

C: Number or Prisoners Living in Louisvilie, by Census Tract

D: Number of Prisoners born in Kentuc$\mathrm{ky}$, by County

E: Schedule used in Study 


\section{LIST OF TABLES}

Table

Page

1. Type of Ot'tense by Race and Sex ........ 21

2. Length of Sentence by Race and Sex ...... 23

6. Previous Commitments to Workhouse by Race and $\operatorname{Sex} . . \cdot . \cdot . \cdot . \cdot . \cdot . \cdot . \cdot 25$

4. Previous Arrests as Recorded by Louisville

Police Department by Race and Sex . . . . . 28

5. Nativity of Parents by Race and Sex ...... 31

6. Nativity by Race and Sex ......... 33

7. Marital Status by Race and Sex ....... 36

8. Type of Dependents by Race and Sex . . . . 38

9. Age by Race and Sex ........... 41

10. Sex by Race . . . . . . . . . . 42

11. Obvious Physical Def'ects Observed by Race and Sex................... 44

12. Stated School Grade Completed by Race and Sex .. 46

13. Age of Leaving School by Race and Sex ..... 47

14. Reason Given for Leaving School by Race and Sex 49

15. Age on Leaving Home by Race and Sex ...... 51

16. Length of Time in City before Commitment by Race and Sex ............. 53

1\% Religion by Race ............ 54

18. Military Service by Race and Sex . . . . 57

19. Means of Support by Race and Sex. . . . . 59

20. Usual Trade or Occupation by Race and Sex ... 61

21. Stated Employment status at lime of Arrest by Roce and Sex ........... 63 
22. Registrations with Kentucky state Employment

Service by Race and Sex ............

23. Number of Louisville and Jefererson County

Social Agencies with Registrations on

Prisoners by Race and Sex .......... 


\section{LIST OH HIGURES}

Figure

Page

1. Number of Prisoners Born in Kentucky

by County ........... 35

2. Residence in City, by Census Tract. . . . . . 54 


\section{CHAPTER I}

HISTORY OF THE WORKHOUSE

The City of Louisville was founded in 1780 , but little

is known of the procedure of caring for the poor and the misdemeanants before 1828. The first institution was a combination of the Poor House and the Workhouse. It was provided for in the Charter of 1828, Section II, Subdivision 70:

The Mayor and Councilmen shall have the power, and it shall be their duty to erect or procure a suitable building or buildings for a Poor House and Workhouse in which the indigent poor shall be comfortably provided for at the expense of the City, to be regulated and managed by suitable persons to be appointed by the Mayor and Councilmen for that purpose, and in apartments distinct from the infirm and indigents. Provision shall be made for confining common beggars, vagrants and all persons who may be sentenced for short periods of confinement. A cormittee of the Board of Councilmen, or special overseers of the poor to be established by the board, who shall place poor persons in the Poor House at their discretion, but the whole establishment shall be under the control and immediate care and subject to the frequent visitation of the Mayor and Councilmen. There was evidently no superintendent to manage the affairs of the Poor House, because it was not until 1851 that it was provided in the Charter that the Poor House Keeper be appointed by the General Council.

The old institution, which was a combination Work-Alms-Pest House, was built sometime prior to 1832. At that time there was the beginning of a movement towerd reform, caused by complaints as to the evil condition of the old place. The old establishment was located on a site memorable in Louisville history, Eighth and Chestnut. It was described in the 1832 City Directory as "a place that accomodates the poor of the City and confines those at labor who do not pay the fines inflicted by the Mayor's Court at the rate of fifty cents a day." 
By a further Amendment to the Charter which was added in 1836, the predecessor of the present Police Court was set up. It was known as the City Court, and replaced an older tribunal known as the Mayor's Court. All persons who were fined by this court were to be confined in the Workhouse until the fines and costs were paid, but the fine might be discharged by labor in the Workhouse at the rate of fifty cents a day. 1

The movement for reform was led by public-spirited citizens who began to achieve results as early as 1835 . For, in December of that year, the City purchased from one Joseph Chamberlain a tract of land known as the Cave Hill Farm, comprising 100 acres of land which now makes up both the Workhouse, Cave Hill Cemetery, and certain other contiguous territory. In 1846, 47.6 acres of this tract were deeded to the Cave Hill Cemetery Company for burial purposes. During this period the entire farm was used by the City for the safe-keeping and punishment by labor of various kinds of persons committed for petty offenses and those of a lesser grade than felonies.

From 1846 to 1851 the Poor House and the Workhouse were evidently operated on the premises of the City Farm. In 1851 an ordinance was passed providing for the erection of cell blocks on this site, and in the same year another ordinance was passed providing for the regulation of the Louisville City Alms House. The Poor House and the Workhouse were now definitely separated. By the Charter of 1851 (Article Vii, section 8) it was provided - "The General Council shall have power, upon lands

I "History of the City Workhouse" Federal Relief Project. Louisville, Kentucky, 1931. 
now provided, or to be provided within or without the city limits, to erect a suitable building or suitable buildings for a City Workhouse." Also, under this amendment the rate of pay for prisoners, to be applied to payment of fines, was raised from fifty cents to seventy-five cents a day.

In 1854 the Council, acting under the power conferred by this Charter, passed an ordinance (\#363): "The Houses enclosures, etc., on the Cave Hill Farm, and all land except so much thereof as may be donated to the trustees of Cave Hill Cemetery shall constitute the Workhouse of the City of Louisville, this name to include the Pest House as well, on the same tract." And thus was established the first Workhouse on the present location to bear that name.

In the same year the Council authorized the Keeper, who was the "Chief officer" to appoint a day guard and night guard, and to keep a record of all prisoners, and to put unruly prisoners in irons if need be. A monthly report was to be made to the Mayor by the Keeper, and an annual report was made to the Council. This shows a trend away from the one absolute control of the Council by giving to the Keeper the power to appoint all subordinate employees, a power once vested directly in the Council. The Keeper was provided with a residence on the premises and was required to live there.

In 1856 an ordinance was passed changing the name of the Keeper to superintendent and divesting him of the power to hire employees and the duty of making the annual report to the General Council. 
No changes were recommended by the Mayor or the Council until 1866, when pressure by the citizens of the community moved Mayor Tomppert to recommend, in his annual message, "That the present Workhouse was too small and the prisoners were too much crowded." The male and female Negro and white prisoners were all in the same cell block, with no segregation and privacy provided for. He also said the quarry was almost exhausted; therefore he recommended the purchase of a new site equipped with a new quarry. The quarry was. very important for it was one of the major sources of income for the Workhouse, as a result of which, in conjunction with a brickyard, the institution was self supporting.

An indication of the changing ideas with regard to penology was that, in 1867, the Mayor requested that a more suitable occupation be found for the women prisoners than manual labor in the quarry, which had been the custom prior to that time. In 1868 Mayor Bunce was not so forceful in his demands for a new Workhouse, although he did recommend that a farm be included in the set-up. In 1869 the Mayor made no mention of the Workhouse in his report. In that year the superintendent described the Workhouse as wholly unfit for the purpose for which it was intended. The pressure of public opinion became so great that the Mayor recommended the floating of a $\$ 200,000$. bond issue for the erection of a new Workhouse, Alms House, and Pest House. Mayor Jacobs called upon the General Council as an immediate representative of the people, to take steps to build a new Workhouse. In February, 1872, the Legislature of the state recognized the 
necessity, and desiring to gratify the prayers of their petitioners authorized the General Council to issue the bonds of the City not to exceed the sum of $\$ 200,000$ in amount, for the purpose of building the Alms House, Workhouse, and Pest House, but the two buildings, the Alms House and Pest House, more than absorbed the entire proceeds of the $\$ 200,000.1$

It is apparent that every administration had recognized the need for a new Workhouse. Several plass were proposed to finance the erection of a new Workhouse, but none of them materialized.

In 1877 the brick manufacturing industry of Louisville was successful in a move to have the Workhouse brickyard closed, because it was competing too much with private enterprise, which was very hard hit by the depression of that time. The brick manufacturers were joined by labor in the movement to close the brickyard.

Due to the closing of the brickyard and an increase in the Workhouse population, there was a deficit of $\$ 4,161.80$ for the year 1877. As a result of this deficit the recommendation of Mayor Jacobs was to divert $\$ 100,000$ from certain special accounts to the Workhouse (these accounts being the Fulton street fill reconstruction, and jail funds), and the funds were set aside for this particular purpose.

In 1879 the new Workhouse was completed. The cost was $\$ 105,000$. The new Workhouse was in reality three wings and a superintendent's quarters, with an office erected around the 
old 1850 cell house. The old structure was never demolished, and it still is in use.

Another significant change occurred about this time. The proportion of Negro to white prisoners began to increase, until in 1888 there were actually more Negroes than whites in the institution. Drunkenness and disorderly conduct remained the principle charges.

In 1893 a new City Charter put the Horkhouse under a new city department - the Board of Public Safety, where it remained until the Charter of 1926 set up the Department of Welfare.

In 1895 a much needed reform from a social point of view was affected. For the first time in the history of the institution the male and female occupants were domiciled in separate quarters. In 1897 the segregation process continued a step further, and the Negroes and whites were segregated and given separate quarters. Also during this year a municipal ordinance established a "Bureau of Workhouse" with officers appointed by the Board of Public Safety.

In 1900 the superintendent decided upon a plan that long term prisoners be given a distinctive uniform for easy identification. These uniforms were purchased in 1902. This, apparently, was due to the large number of escapes in the past few years.

From 1903 to 1926 arailable sources indicate that conditions as they rela te to this study of the Workhouse remained virtually unchanged.

In 1926 Louisville received a new city charter which 
supplanted the old strong council-weak mayor type. The old system of administrative boards was supplanted by the present departmental system. A new organization was created by this charter, known as the Department of Public Welfare, which took control of functionally connected activities of goverment which had been scattered throughout the city government. The City ordinance, which became effective after the municipal election of 1929, transferred from the former Board of Safety, the Home for the Aged and Infirm and the Workhouse; from the former Board of Works, cemeteries, public comfort stations and public baths; from the Board of Parks Commissioners, the Recreation Department, and placed them all in the new Department of Public Welfare. ${ }^{1}$ The Department did not come into existence until January 1, 1930.

Previous to 1931, the operation at the rock quarry on Grinstead Drive had been stopped by injunction. The first duty of the new Department of Public Welfare was to secure a place where rock could be quarried, so that the prisoners could be kept busy. The second, was to lay out a plan for a new Workhouse program.

After much search, a quarry and a hundred and eighty acre farm was located at Avoca, Kentucky. It was felt that the ideal program for a new Workhouse would be an arrangement combining quarry operations for profit, and a farm and dairy operation for the maintenance of the Workhouse prisoners and staff. It was also recommended that at the earliest possible moment a trained

1 See Appendix A. p. 75 
Social Worker be assigned to the Workhouse. 1

In 1934 a physicion was added to the staff to provide more adequate medical care. Since a large majority of those sent to the Workhouse needed medical attention, it was apparent that this service was an important step toward the rehabilitation of the inmates. 2

For several years, the City Workhouse maintained and operated the farm and quarry at Avoca station. Because of the poor farming land and the expense involved in operation, the property was surrendered to its owner in February, 1935. Farm equipment and livestock were transferred to the Home for the Aged and Infirm. In the spring of 1935 plans for a modern penal institution were drawn and submitted for construction as a Works Projects Administration project, by the Director of Welfare, but lack of City revenues prevented this construction.

Effective September 1, 1935, the operation of the farm of 307 acres was transferred from the Supervisor of the Home for the Aged and Infirm to the City Workhouse, as recommended by the Griffenhagen Report. Prisoners were transported daily from the Workhouse to work on this farm and to do maintenance work at the Home for the Aged and Infirm. A barracks to house 26 prisoners was later built on the farm to reduce the problem of transportation. Prisoners al so were assi gned to do work at the City cemeteries and to a variety of other city work projects.

1 Department of Public Welfare, Annual Report Fiscal Year June 30, 1931 to July 1, 1932 Louisville, Kentucky, Foreword, p.2. 2 Department of Public Welfare, Annual Report Fiscal Year June 30, 1933 to July 1, 1934 LouisvilIe, Kentucky, p. 32. 
In 1937 a clinic for the detection and treatment of venereal diseases was set up. 1

on September 1, 1938, a Social Work unit was established on an experimental basis. This was to be the second major step in transforming the Workhouse from a place of simply useless, unproductive confinement to one of rehabilitative, correctional and constructive purposes. 2 In conformity with the purpose of this institution a system of parole was established. With only one social worker for the entire population, the opportunity for parole was of necessity limited to the first offender, to the very young offender, to persons with potentialities for rehabilitation and to persons with medical problems. The advantages of such a system were numerous and obvious. A case type of prisoner record was established. The Social Work unit became a permanent part of the progrem in September, 1939. As part of the Social Work unit, a Works Progress Administration recreation project with a full-time recreation leader and an instructor in sewing, weaving and handicraft was added in Jenuary, 1942. When the Works Progress Administration was dissolved in February, 1943, the Department of Welfare retained these employees as part of the permanent staff of the Workhouse.

In February, 1941, the Workhouse was designated to serve as a detention center for women committed on writs of quarantine as part of the venereal disease control program organized under the

1 Department of Public Welfare, Annual Report Fiscal Year June 30,1936 to July I, 1937 Louisvil Ie, Kentucky, p. 14. 2 Department of Public Welfare, Annual Report Fiscal Year June 30, 1937 to July 1, 1938 Louisvilie, Kentucky, p. 33. 
United States Medical Department of Fort Knox and the Louisville Department of Health. Major emphasis in treatment of prisoners was given these female commitments and in July, 1942, a social worker from the Municipal Bureau of Social Service, another division of the Department of Public Welfare, was assigned to the Workhouse to aid in the treatment of these prisoners. ${ }^{1}$ A full-time women social worker was added to the staff in September, 1943. During the period that the Workhouse served as a detention center for women committed on writs of quarantine, the Health Department through the United States Public Health Service, assigned a doctor 3 days por week and a nurse was added to the staff. The nurse was retained on the Workhouse staff after the Workhouse ceased to serve as a detention center in July, 1945.

The present social work unit (1949) includes a Social Work Supervisor who devotes half-time to case work and half-time to supervision of the unit and of a workshop for the inmates, a fulltime senior social worker, a student worker on three-fourths time, and two half-time recreation workers, one for the male prisoners and one for the female prisoners. In addition, the services of a graduate student in psychology are arailable for testing purposes through the University of Louisville. Medical services are also available to prisoners at the Workhouse.

In 1944 the Welfare Committee of the Louisville Area Development Association, as part of its study of public welfare in Louisville, directed its efforts toward planning for the building of a

I Department of Public Welfare, Annual Report Fiscal Year
June 30, 1941 to July 1, 1942 Louisvilie, Kentucky, p. 49.


modern penal f'arm which will combine the sentenced population of the Jail and the entire Workhouse population, and of ter a complete modern program of rehabilitation. The Sub-Committee on the Workhouse and Jail which had been appointed by the Committee on Wellare reported October, 1944, that they had encountered administrative difficulties because of the separation of the City and County Departments of Welfare.

The Welfare Committee studying the other welfare services in addition to that of the penal program drafted a bill creating a City-County Welfare Board ${ }^{l}$ which would have as one of its functions the administration of the proposed penal farmo The late Mayor E. Leland Taylor included the consolidation of the jail and Workhouse and the establishment of a modern penal farm as part of his platform and included the bill creating the City-County Welfare Board in his 1946 legislative program. This bill, a permissive law, was introduced in the 1946 General Assembly and passed. However, the actual consolidation was not brought about. The JailWorkhouse Subcommittee of the Committee on Institutions of the Louisville Council of Churches, seeing that a consolidated program was stalemated, introduced a bill which passed the 1948 General Assembly which would give the County the right to set up a penal farm and accept City prisoners. A committee appointed by the Jefferson County Judge to make recommendations for the establishment of the penal institution, after a series of meetings came to the conclusion that a consolidated program was the answer to the

1 Jails and Workhouse. A Report Prepared by Sub-Committee of Workhouse Welfare Committer, Louisville Area Development Association, Louisville, Kentucky; June 29, 1944. (mimeographed). 
problem. Following that recommendation the County Judge and the Nayor of Louisville in February, 1949, appointed a joint committee of City and County officials, interested citizens, and members of the Louisville Council of Churches to develop a program for a joint City-County penal farm. That committee has held several meetings but has not made its final report. Present indications are that a consolidated development will require time for its accomplishment.

The City Weltare Department, as an interim program, has plans under way to move from the present outmoded Workhouse, which is in need of heavy expenditure for repairs, to the present building of the Home for the Aged and Infirm, if the Marine Hospital is secured for use for the program of the Home for the Aged and Infirm. The building of the Home for the Aged and Int'irm will provide more modern tacilities for all parts of the program. Its location on the Welfare Farm will enable the use of a larger number of prisoners on the f'arm and will solve the problem of transportation. Additional buildings will make possible an expanded work program. Directors of welfare have, through the years, recommended the establishment of a modern penal system at the City Workhouse, but limited city revenues have prevented the construction of a modern building. Additional revenue made possible through the income from the City Occupational Tax will permit the move of the Workhouse to improved quarters if the Marine Hospital can be secured. A bill has been introduced in Congress to permit the City of Louisville to make the purchase. 
CHAPTER II

INTRODUCTION TO THE STUDY

Purpose

The purpose of this study is to gain an understanding of the people who find their way into the City Workhouse. Progressive thought has come to regard the old fashioned Workhouse as unsatisfactory for the incarceration of persons under sentence, who are composed of unstable and maladjusted individuals who are comnitted f'or petty misdemeanors such as drunkenness, disorderly conduct, vagrancy, and prostitution. The causative f'actors, court procedure, and the jurisdiction of prisoners are discussed only as they relate to who these people are who come to the City Workhouse.

On July 30 , 1948, an invitation was extended to the Raymond A. Kent School of Social Work of the University of Louisville from Miss Louise Diecks, Director of City Welfare, to make a study of the types of people who become the responsibility of an institution such as the City Workhouse. 1 In her opinion, "the scientific treatment of such persons will develop in the not too distant future. The treatment of such persons is largely an unexplored field and one which communities will be obliged to Iace and do something about."

Modern penology holds that effective community action is important in dealing with this group. Jobs can be found for many of them. Medical treatment might well clear up many of'

1 See Appendix B, p. 76. 
their difficulties. Social clinics would answer the problems most ef'ectively, but since they are so infrequent throughout the country, the common method is to put these persons in jail, keep them there a brief period, and then release them to the same situation as prevailed before. Thus, they go through the institutional treadmill periodically; a liability to their families and the community.

On December 21, 1948 the committee met with Miss Diecks to make plans for the study of the Workhouse population. Because of the broad scope of the problem, it was deemed advisable to divide the study into three phases. These are: who is comitted to the Workhouse, why are they committed (the causes of the delinquent behavior), and study of the Workhouse program of rehabilitation and control. This study is primarily concerned with the first phase, "Who is Committed to the City Workhouse?"

\section{Previous Studies}

Previously, three studies have been made on the Louisville City Workhouse. A 1937 study found that by comparison the Louisville City Workhouse was not unique or unusual in the characteristics of the inmates. A typical inmate was a "white male, in his thirties, with less than 8th grade education, unemployed at the time but when working, an unskilled laborer, committed on a charge of drunkenness or disorderly conduct with a record of previous commitments on the same or similar charges." I

1 Reiger, Charles J. Jr., "The Louisville City Workhouse." unpublished paper, Department of Sociology, University of Louisville, 1937. 
Another study, on social treatment, looked at the job with an eye for improving the treatment technique in the City Workhouse. In this study it was stated that modern psychology and social treatment principles define behavior as being only symptomatic. The outward behavior of the delinquent reflects a much deeper problem which has been allowed to grow over a long period of time in a succession of retrogressive experiences. The writer asserted that nothing can be done with a problem where there is no understanding of the factors contributing to the behavior which lead to arrest and commitment. He described the prisoner as one who through enviroment and unfavorable experiences has become so emotionally unstable as to be without any regard for the consequences of his own behavior. 1

In May, 1948, a survey of the male prisoners in the Workhouse found the average male prisoner to be white, married but not living with his tamily, having a seventh grade education, and employed at the time of commitment. Seventy-two per cent had previous workhouse sentences. 2

\section{Scope and lifethod}

After discussing the problem of securing an adequate sample of the workhouse prisoners wi th Mr. Eugene Thompson, Administrative Assistant, City Weltare Department, and the

1 Crumley, James J. "The Workhouse Prisoner a Problem in Social Treatment." Unpublished Report, 1941.

2 Thompson, Eugene $\mathrm{T}$. "City Workhouse Population of Male Prisoners." Unpublished Report, Department of Welfare, Louisville, Kentucky, June, 1948. 
social worker at the City Workhouse, a study of the records at the Workhouse was made. It was decided that an adequate sample of the typical inmates could be obtained by interviewing every person committed to the Workhouse f'or a period of two weeks. Ihe average number committed in a one week period is approximately one hundred. It was decided to obtain the basic information about inmates by a study of Workhouse records, records of previous arrests, any records listed by the local Social Service Exchange, and personal interviews with the inmates at the time of comitment. The plan was to interview inmates at the Workhouse at the time of admission, with the exception of female Negro prisoners. This last group are housed at the County Jail and periodic visits were made tor interviews there. A schedule was adopted to record the statements given by the inmates and the information secured from collateral sources. The items included personal, social, economic, and criminal data that would show the characteristics of persons being committed to the Workhouse.

\section{Composition of the Sample}

The 214 men and women committed to the Workhouse during the two week period, February 28 to March 12, 1949, were consecutively interviewed as they were committed, with the exception that two men and one woman were committed twice during that period and were interviewed only the first time. Included in the total was one Negro male juvenile who was committed through error and was transterred to Juvenile Court. Not included in the total was 
one white male who was committed but released before he could be interviewed. The total commitments for the same period was 213 in 1948 and 137 in 1947. The 214 prisoners committed consisted of 162 white and 52 Negro men and women; 130 white male prisoners and 32 white temale prisoners made up the total white group and the Negro group was composed of 47 male and 5 t'emale prisoners.

The sample is 75.7 per cent white and 24.3 per cent Negro, which corresponds with the 213 comitments for the same period in 1948 when 78.4 per cent were white and 21.6 per cent were Negroes. The composition of the sample was found to be typical as to race and also as to oftense within the white and Negro groups.

\section{Cormitment Procedure}

Persons are admitted to the City Workhouse in Louisville from three sources; the Police Court, the Juvenile Court, and the Quarterly Court. Persons are received trom Police Court daily by f'ormal commitment. They may be committed tor specific sentences, or upon their f'ailure to pay a prescribed fine demanded by the Court, or f'or both. In cases of fines, the term of imprisonment is regulated at the rate of $\$ 2.00$ per day. For example, a person failing to pay a $\$ 10.00$ fine would not be eligible for discharge until tive days elapsed. The day upon which a person is committed is counted as a tull day regardless of the hour of admission. A person serving a term because of non-payment of f'ine may be released upon presentation of a "Paid Fine Release" obtained from the Clerk of the Police Court after 
payment of the balance of the original tine, after deduction has been made of $\$ 2.00$ per day I'or the time served. By statute, the court loses jurisdiction three days after tormal commitment. At that time complete responsibility passes to the Department of Welfare.

Persons committed to the City Workhouse by the Jefierson County Juvenile Court are usually charged with contributing to the dependency or delinquency of minors or with failure to provide support. These comitments carry either t'ines or specitic sentences, or both. Terms of imprisonment are served in the same manner as those received from the Police Court with the exception that at no time does the Juvenile Court lose its jurisdiction and at no time does that responsibility pass into the hands of the Depertment of Welfare, Persons are admitted from the Juvenile Court on a boarding basis which is paid from County funds at the rate of $\$ 1.00$ per day. Persons committed trom the Jelierson County Quarterly Court have the same status as those committed from Juvenile Court, except that in most of these cases the charges involve petit larceny, vagrancy, disorderly conduct, and other misdemeanors.

Because there are so few Negro women committed to the Workhouse, and because more cell blocks are needed to house white male prisoners, the Negro women are boarded in the County Jail, and $\$ 1.50$ per day per person is paid the County trom City Iunds. New prisoners received at the Workhouse were given a bath and the institution clothing and were brought directly into the interviewing room, where they were examined by the project inter- 
viewer, who obtained the desired information from each person.

All cases were cleared with Social Service Exchange in Louisville, and about 68 per cent were identified ( 72 per cent of the white and 56 per cent of the Negro cases). Only the list of social agencies having had contact with the inmate or his family, if any, was secured. While the agencies represent a source of valuable personal and social information about the 68 per cent registered, no contact was made with them to study the case records.

The Identification Bureau of the Louisville Police Department provided a sumary of the criminal record on file for each prisoner. The Kentucky Employment Service provided information on those registered with the agency for employment. About 72 per cent were not known to the employment service. Of the 28 per cent registered only about 12 per cent were active with the agency• 


\section{CHAPTER III}

CURRENT OFFENSH AND PRIOR CRIMINAL RECORD

\section{Offense}

Two hundred fourteen cases were studied. Ot the 130 white males cormitted to the Workhouse as shown in Table 1, page 2l, 54.7 per cent were committed for drunkenness. The next largest groups are disorderly conduct $14 . \%$ per cent, vagrancy 13.9 per cent, and loitering 10.8 per cent. Among the white t'emeles committed to the Workhouse, 31.3 per cent were committed ror disorderly conduct and $3 \not{l} .3$ per cent Ior vagrancy. The next largest group was committed tor drunkenness (18.8 per cent).

Among the Negro males committed to the Workhouse, 34 per cent were committed for disorderly conduct. The next largest groups were drunkenness, 27.7 per cent, and vagranoy 23.4 per cent. Among the 5 Negro temales committed to the Workhouse, 2 were committed tor disorderly conduct, 1 for drunkenness, 1 tor vagrancy, and 1 tor vagrancy and loitering.

Included under "other" in Table 1 were the following charges: exposure of person, reckless driving, driving without operators license, violation of fire prevention ordinance, drunk and disorderly conduct, vagrancy and prostitution, and loitering and disorderly conduct.

For the total sample, 42.4 per cent were committed for drunkenness, 22 per cent for disorderly conduct, 18.7 per cent tor vagrancy, and 7.5 per cent tor loitering. The types of of'tenses do not necessari- 
TABLE 1

TYPE OF OFFENSE BY RACE AND SEX

\begin{tabular}{|c|c|c|c|c|c|c|c|c|c|c|c|c|c|c|}
\hline \multirow{3}{*}{ Offense } & \multicolumn{2}{|c|}{ Total } & \multicolumn{6}{|c|}{ Wh $i t e$} & \multicolumn{6}{|c|}{$N \odot g r o$} \\
\hline & \multicolumn{2}{|l|}{. } & \multicolumn{2}{|r|}{ Total } & \multicolumn{2}{|r|}{ Male } & \multicolumn{2}{|c|}{ Female } & \multicolumn{2}{|r|}{ Total } & \multicolumn{2}{|r|}{ Male } & \multicolumn{2}{|c|}{ Female } \\
\hline & No. & $\begin{array}{l}\text { Per } \\
\text { cent }\end{array}$ & No. & $\begin{array}{l}\text { Per } \\
\text { cent }\end{array}$ & No. & $\begin{array}{l}\text { Per } \\
\text { cent }\end{array}$ & No. & $\begin{array}{l}\text { Per } \\
\text { cent }\end{array}$ & No. & $\begin{array}{l}\text { Per } \\
\text { cent }\end{array}$ & No. & $\begin{array}{l}\text { Per } \\
\text { cent }\end{array}$ & No. & $\begin{array}{l}\text { Per } \\
\text { cent }\end{array}$ \\
\hline Total --- & -214 & 100 & 162 & 100 & 130 & 100 & 32 & 100 & 52 & 100 & 47 & 100 & 5 & 100 \\
\hline Drunkenness - - - & 91 & 42.4 & 77 & 47.5 & 71 & 54.7 & 6 & 18.8 & 14 & 26.9 & 13 & 27.7 & 1 & 20.0 \\
\hline Disorderly conduct & 47 & 22.0 & 29 & 18.0 & 19 & 14.7 & 10 & 31.3 & 18 & 34.5 & 16 & 34.0 & 2 & 40.0 \\
\hline Vagrancy - - - - & 40 & 18.7 & 28 & 17.3 & 18 & 13.9 & 10 & 31.3 & 12 & 23.1 & 11 & 23.4 & 1 & 20.0 \\
\hline Loitering - - - & 16 & 7.5 & 14 & 8.7 & 14 & 10.8 & - & - & 2 & 3.9 & 2 & $4 \cdot 3$ & - & - \\
\hline $\begin{array}{l}\text { Vagrancy and } \\
\text { Disorderly conduct }\end{array}$ & 4 & 2.0 & 3 & 1.9 & 1 & 0.7 & 2 & 6.2 & 1 & 1.9 & 1 & 2.1 & - & - \\
\hline Security warrant - & 3 & 1.4 & 1 & 0.6 & 1 & 0.7 & - & - & 2 & 3.9 & 2 & 4.3 & - & - \\
\hline Breach of peace - & 2 & 0.9 & 2 & 1.2 & 2 & 1.5 & - & - & - & - & - & - & - & - \\
\hline Reckless driving - & 2 & 0.9 & 1 & 0.6 & 1 & 0.7 & - & - & 1 & 1.9 & 1 & 2.1 & - & - \\
\hline $\begin{array}{l}\text { Vagrancy and } \\
\text { Loitering }-\ldots-\ldots\end{array}$ & 2 & 0.9 & 2 & 1.2 & - & - & 2 & 6.2 & $\rightarrow$ & - & - & - & - & - \\
\hline Other $-\cdots$ & 7 & 3.3 & 5 & 3.0 & 3 & 2.3 & 2 & 6.2 & 2 & 3.9 & 1 & 2.1 & 1 & 20.0 \\
\hline
\end{tabular}


ly give a true picture of' the reason tor the person's arrest. In many instances the charges were amended in Police Court. Many of the f'emale white prisoners gave the reason f'or commitment as "prostitution", although the charge was recorded as vagrancy or disorderly conduct. Many drunkenness charges among the white and Negro males were also amended to charges of disorderly conduct, vagrancy and loitering.

\section{Length of Sentence}

Just as of'lenses were petty, so the sentences given to the group studied were short, as is shown in Table 2 on page 25. Sixty-one prisoners, or 28.5 per cent of the group, were serving sentences of 5 days or less. Forty-two prisoners, or 19.7 per cent, were serving sentences of trom 6 to 10 days. Sixty-nine prisoners, or 32.2 per cent, had sentences of 21 to 30 days. The usual sentence for transients was thirty days. The concentration on short terms was such that only about 11.2 per cent had sentences of more than 60 days. The percentages were about the same f'or each race in the length of sentence. Information on t'ines indicates that 108, or 50.5 per cent of the sample group, had been committed in det'ault of a fine. ${ }^{1}$ Inability to pay was the governing reason in almost all cases. Twenty-eight of the 47 Negro males, or 60 per cent, were committed in derault of a fine, in comparison with 59 per cent of the white males. Trenty-six, or 12.1 per cent of the somple, had t'ines

1 Length of sentence was tabulated in Table 2 tor this group on the basis of $\$ 2.00$ per day. 
TABLE 2

LENGTH OF SENTENCE BY RACE AND SEX

\begin{tabular}{|c|c|c|c|c|c|c|c|c|c|c|c|c|c|c|}
\hline \multirow{3}{*}{ Length of Sentence } & \multirow{2}{*}{\multicolumn{2}{|c|}{ Total }} & \multicolumn{6}{|c|}{$\nabla h i t e$} & \multicolumn{6}{|c|}{$N \in g r o$} \\
\hline & & & \multicolumn{2}{|c|}{ Total } & \multicolumn{2}{|c|}{ Male } & \multicolumn{2}{|c|}{ Female } & \multicolumn{2}{|c|}{ Total } & \multicolumn{2}{|r|}{ Male } & \multicolumn{2}{|c|}{ Female } \\
\hline & No. & $\begin{array}{l}\text { Per } \\
\text { cent }\end{array}$ & No. & $\begin{array}{l}\text { Per } \\
\text { cent }\end{array}$ & No. & $\begin{array}{l}\text { Per } \\
\text { cent }\end{array}$ & No. & $\begin{array}{l}\text { Per } \\
\text { cent }\end{array}$ & No. & $\begin{array}{l}\text { Per } \\
\text { cent }\end{array}$ & No. & $\begin{array}{l}\text { Per } \\
\text { cent }\end{array}$ & No. & $\begin{array}{l}\text { Per } \\
\text { cent }\end{array}$ \\
\hline Total - - & 214 & 100 & 162 & 100 & 130 & 100 & 32 & 100 & 52 & 100 & 47 & 100 & 5 & 100 \\
\hline $1-5$ days - - & 61 & 28.5 & 45 & 27.8 & 40 & 30.8 & 5 & 15.6 & 16 & 30.7 & 15 & 31.9 & 1 & 20.0 \\
\hline $6-10$ days -- & 42 & 19.7 & 29 & 17.9 & 25 & 19.2 & 4 & 12.5 & 13 & 25.0 & 9 & 19.2 & 4 & 80.0 \\
\hline $11=20$ days - & 18 & 8.4 & 13 & 8.0 & 11 & 8.4 & 2 & 6.3 & 5 & 9.8 & 5 & 10.7 & - & - \\
\hline 21 - 30 days - - & 69 & 32.2 & 53 & 32.7 & 40 & 30.8 & 13 & 40.6 & 16 & 30.7 & 16 & 34.0 & - & - \\
\hline Over 30 days - - & 24 & 11.2 & 22 & 13.6 & 14 & 10.8 & 8 & 25.0 & 2 & 3.8 & 2 & 4.2 & - & - \\
\hline $\begin{array}{l}\text { Average } \\
\text { Sentence (days) - }\end{array}$ & & & & & & & & & & & & 4 & & 7 \\
\hline
\end{tabular}


alternative to part of the sentence, $i . \theta .$, they were committed on two or more counts, fior one of which they received a straight sentence and for the other a fine with imprisoment as the alternative. Ot the 108 prisoners on which tines were imposed, 92 prisoners, or 85.2 per cent were for $\$ 25$ fines or less, with $\$ 10$ as the most frequent. The smallest sentence imposed was tor a $\$ 2.00$ tine, while the longest sentence imposed was 118 days. The difterence in length of sentence is probably related to the racial ditference in character of offenses, since intoxication as a rule was the charge against the white man, while a substantial proportion of the Negro group were committed for disorderly conduct, for which shorter sentences are given. The white group as a whole received longer sentences than the Negro group. Twenty-two, or 13.6 per cent of the white prisoners, had sentences of more than thirty days, as compared to 3.8 per cent t'or the Negro group.

\section{Previous Commitments}

As is shown in Table 3, page 25, 40.6 per cent of the total group had no previous commitments to the Workhouse, $y .8$ per cent had one previous commitment, 8.3 per cent had two previous commitments, and 'S'S per cent had 5 or more previous commitments. Fif'ty-nine of the 162 white prisoners, or 36.5 per cent, nad no previous comitments to the Workhouse, as compared to 28 , or 53.9 per cent, of the 52 Negro prisoners.

The white male prisoners have the highest average number of previous commitments to the Workhouse (18 commitments). The white I'emales 
TABLE 3

PREVIOUS COMMITMENTS TO WORKHOUSE BY RACE AND SEX

\begin{tabular}{|c|c|c|c|c|c|c|c|c|c|c|c|c|c|c|}
\hline \multirow{3}{*}{ Previous Commitments } & \multirow{2}{*}{\multicolumn{2}{|c|}{ Total }} & \multicolumn{6}{|c|}{$W h i t e$} & \multicolumn{6}{|c|}{$N \in g r o$} \\
\hline & & & \multicolumn{2}{|c|}{ Total } & \multicolumn{2}{|c|}{$\mathrm{Ma}$ e } & \multicolumn{2}{|c|}{ Female } & \multicolumn{2}{|c|}{ Total } & \multicolumn{2}{|c|}{ Male } & \multicolumn{2}{|c|}{ Female } \\
\hline & No. & $\begin{array}{l}\text { Per } \\
\text { cent }\end{array}$ & No. & $\begin{array}{l}\text { Per } \\
\text { cent }\end{array}$ & No. & $\begin{array}{l}\text { Per } \\
\text { cent }\end{array}$ & No. & $\begin{array}{l}\text { Per } \\
\text { cent }\end{array}$ & No. & $\begin{array}{l}\text { Per } \\
\text { cent }\end{array}$ & No. & $\begin{array}{l}\text { Per } \\
\text { cent }\end{array}$ & No. & $\begin{array}{l}\text { Per } \\
\text { cent }\end{array}$ \\
\hline Total - - & 214 & $100 \cdot$ & 162 & 100 & 130 & 100 & 32 & 100 & 52 & 100 & 47 & 100 & 5 & 100 \\
\hline None - - - - - & 87 & 40.6 & 59 & 36.5 & 53 & 40.8 & 6 & 18.8 & 28 & 53.9 & 23 & 48.9 & 5 & 100 \\
\hline $1--\cdots-\cdots$ & 21 & 9.8 & 17 & 10.5 & 15 & 11.6 & 2 & 6.2 & 4 & 7.6 & 4 & 8.5 & - & - \\
\hline $2-\cdots-\cdots-\cdots$ & 18 & 8.3 & 15 & 9.3 & 12 & 9.2 & 3 & 9.4 & 3 & 5.8 & 3 & 6.4 & - & - \\
\hline $3----\cdots$ & 10 & 4.6 & 7 & $4 \cdot 3$ & 6 & 4.6 & 1 & 3.1 & 3 & 5.8 & 3 & 6.4 & - & - \\
\hline $4--\cdots-\cdots$ & 8 & 3.7 & 6 & 3.7 & 4 & 3.1 & 2 & 6.2 & 2 & 3.9 & 2 & $4 \cdot 3$ & - & - \\
\hline $5-9---\cdots$ & 22 & 10.2 & 17 & 10.5 & 14 & 10.8 & 3 & 9.4 & 5 & 9.6 & 5 & 10.6 & - & - \\
\hline $10-19-\cdots-$ & 19 & 8.8 & 15 & 9.2 & 8 & 6.1 & 7 & 21.9 & 4 & 7.6 & 4 & 8.5 & - & $m$ \\
\hline $20-39-\cdots-$ & 18 & 8.4 & 17 & 10.4 & 10 & 7.7 & 7 & 21.9 & 1 & 1.9 & 1 & 2.1 & - & - \\
\hline 40 - and over - - & 11 & 5.6 & 9 & 5.6 & 8 & 6.1 & 1 & 3.1 & 2 & 3.9 & 2 & 4.3 & - & - \\
\hline $\begin{array}{l}\text { Average number } \\
\text { prior commi tments }\end{array}$ & & 4 & & 7 & & 8 & & 1 & & 6 & & 7 & & 0 \\
\hline
\end{tabular}


had the next nighest average (II commitments). The Negro males had an average of 7 previous commitments while the tive Negro temeles had no record of previous commitments.

It may be noted that of the white temales only 18.8 per cent had no previous commitments, as compared to 40.8 per cent of the white males, and 48.9 per cent of the Negro males.

Table 3 shows that 40.8 per cent of the 130 white males had no previous commitments to the Workhouse, 24.6 per cent had trom 5 to 39 previous commitments, and 6.1 pe $r$ cent had 40 or more prior commitments. Two white males have a record of more than 100 commitments each. The highest number in the sample group was 135 prior commitments accumulated over a period of 25 years, an average of about t'ive a year.

Among the 32 white temales, 18.8 per cent had no previous commitments to the Workhouse, 53.2 per cent have had I'rom 5 to 39 commitments, and 3.1 per cent had 40 or more previous commitments. The highest number of previous commitments among the white temales was 43 accumulated over a period of 10 years, an average of' about f'our commitments a year.

of the 47 Negro males, 48.9 per cent had no previous commitments to the Workhouse, 21.2 per cent had f'rom 5 to 39 previous commitments, and 4.3 p r cent had 40 or more previous commitments. The highest number of previous commitments among the Negro males was 109 accumulated over a period of 29 years, an average of about tour commitments a year. 


\section{Previous Arrests}

The main sources of information fior the data on past arrests were the Workhouse records and the records of the Louisville Police Department, which are based upon fingerprints and photograph identitication in all t'elony cases but in only a f'ew misdemeanant cases. Most petty offenders are identified in the police tiles merely by name, age, race and the precinct in which arrested, but in spite of this limitation on making correct identification, the police record is valuable because it shows many convictions (within the city) which result not in commitments but in forteits, fines, posting of personal bond, and probation, as well as arrests which do not result in conviction at all. The chiet gap in the data is the lack of information on convictions and commitments for misdemeanors in other jurisdictions, since it is not the practice throughout the country to fingerprint all misdemeanants and clear the results with a central bureau. This means that fines paid outside the city of Louisville and short sentences served in local jails elsewhere are not recorded, and there is no practicable way to obtain complete data on these points.

As shown in Table 4, page 28, only 12.6 per cent of the total group have no record of previous arrests. About ten per cent of the white prisoners and twenty-three per cent of the Negro prisoners have only one arrest recorded. Ot the total group, about 57 per cent have been arrested more than 4 times, and 4 white males and 1 Negro male actually have a record of more than 100 previous arrests. The highest number of arrests recorded for the persons studied is 
TABTE 4

PREVIOUS ARRESTS AS RECORDED BY LOUISVILLE POLICE DEPARTMENT BY RACE AND SEX

\begin{tabular}{|c|c|c|c|c|c|c|c|c|c|c|c|c|c|c|}
\hline \multirow{3}{*}{ Previous Arrests } & \multirow{2}{*}{\multicolumn{2}{|c|}{ Total }} & \multicolumn{6}{|c|}{$w h i t e$} & \multicolumn{6}{|c|}{$N \in g r 0$} \\
\hline & & & \multicolumn{2}{|c|}{ Total } & \multicolumn{2}{|c|}{ Male } & \multicolumn{2}{|c|}{ Female } & \multicolumn{2}{|c|}{ Total } & \multicolumn{2}{|c|}{ Male } & \multicolumn{2}{|c|}{ Femaje } \\
\hline & No. & $\begin{array}{l}\text { Per } \\
\text { cent }\end{array}$ & No. & $\begin{array}{l}\text { Per } \\
\text { cent }\end{array}$ & No. & $\begin{array}{l}\text { Per } \\
\text { cent }\end{array}$ & No. & $\begin{array}{l}\text { Per } \\
\text { cent }\end{array}$ & No. & $\begin{array}{l}\text { Per } \\
\text { cent }\end{array}$ & No. & $\begin{array}{l}\text { Per } \\
\text { cent }\end{array}$ & No. & $\begin{array}{l}\text { Per } \\
\text { cent }\end{array}$ \\
\hline Total - - & 214 & 100 & 162 & 100 & 130 & 100 & 32 & 100 & 52 & 100 & 47 & 100 & 5 & 100 \\
\hline No arrest --- & 27. & 12.6 & 24 & 14.8 & 18 & 17.0 & 6 & 18.8 & 3 & 5.8 & 3 & 6.4 & - & - \\
\hline 1 arrest $-\ldots$ & 28 & 13.3 & 16 & 9.9 & 14 & 12.3 & 2 & 6.2 & 12 & 23.1 & 8 & 17.0 & 4 & 80.0 \\
\hline 2 arrests -- & 14 & 6.4 & 8 & 5.0 & 7 & 4.6 & 1 & 3.1 & 6 & 11.5 & 6 & 12.8 & - & - \\
\hline 3 arrests $-\infty$ & 14 & 6.4 & 8 & 5.0 & 8 & 5.4 & - & - & 6 & 11.5 & 6 & 12.8 & - & - \\
\hline 4 arrests -- & 9 & 4.2 & 6 & 3.7 & 5 & 3.9 & 1 & 3.1 & 3 & 5.8 & 3 & 6.4 & - & - \\
\hline 5 to 9 arrests- & 35 & 16.4 & 27 & 16.6 & 22 & 16.2 & 5 & 15.7 & 8 & 15.4 & 7 & 14.9 & 1 & 20.0 \\
\hline 10 to 19 arrests- & 24 & 11.2 & 18 & 11.1 & 16 & 13.7 & 2 & 6.2 & 6 & 11.5 & 6 & 12.8 & - & $=$ \\
\hline 20 to 39 arrests- & 29 & 13.6 & 27 & 16.6 & 20 & 12.3 & 7 & 21.8 & 2 & 3.9 & 2 & $4 \cdot 2$ & - & - \\
\hline 40 to 59 arrests- & 21 & 9.8 & 17 & 10.5 & 12 & 8.5 & 5 & 15.7 & 4 & 7.6 & 4 & 8.5 & - & - \\
\hline 60 arrests and over & 13 & 6.1 & 11 & 6.8 & 8 & 6.1 & 3 & 9.4 & 2 & 3.9 & 2 & 4.2 & - & - \\
\hline $\begin{array}{l}\text { Average number of } \\
\text { previous arrests }\end{array}$ & & & & & & 2 & & 4 & & 4 & & 4 & & 3 \\
\hline
\end{tabular}


231 accumulated during a pe riod of about 25 years.

The average number of previous arrests for the entire group

is 12. As is shown in Table 4 the average for male and temale

white prisoners is appreciably higher than for the male and female Negro prisoners. 


\section{FAMILY BACKGROUND}

\section{Nativity of Parents}

The information on nativity of parents was based on statements made by the prisoners to the interviewer in the course of the social history interview. Vertication of the statements concerning tamily background was not made.

In some cases the prisoners did not know where their parents were born, but there was no hesitation in giving the information when known. Table 5, page 31, indicates that 48 per cent of the grisoners came trom t'amilies in which both parents were born in Kentucky. Parents of the Negroes are almost wi thout exception from the Southeastern States, it cases are included in which one parent is known to be Irom Kentucky and the nativity of the other is unknown. The birthplace of parents was not known by 11.7 per cent of the group studied.

It may be noted that 53 per cent of the parents of the white group were born in Kentucky, as compared to 32.6 per cent of the parents of the Negro group. This may be traced to the tendency of the Negro population to migrate from states south of Kentucky toward the Northern States, in search of better opportunities. 
TABLE 5

NATIVITY OF PARENTS BY RACE AND SEX

\begin{tabular}{|c|c|c|c|c|c|c|c|c|c|c|c|c|c|c|}
\hline \multirow{3}{*}{ Nativity of Parents } & \multicolumn{2}{|c|}{ Total } & \multicolumn{6}{|c|}{$w h i t e$} & \multicolumn{6}{|c|}{$N$ e g ro } \\
\hline & & & \multicolumn{2}{|c|}{ T'otal } & \multicolumn{2}{|c|}{ Male } & \multicolumn{2}{|c|}{ Female } & \multicolumn{2}{|c|}{ Total } & \multicolumn{2}{|c|}{ Male } & \multicolumn{2}{|c|}{ Female } \\
\hline & No. & $\begin{array}{l}\text { Per } \\
\text { cent }\end{array}$ & No. & $\begin{array}{l}\text { Per } \\
\text { cent }\end{array}$ & No. & $\begin{array}{l}\text { Per } \\
\text { cent }\end{array}$ & No. & $\begin{array}{l}\text { Per } \\
\text { cent }\end{array}$ & No. & $\begin{array}{l}\text { Per } \\
\text { cent }\end{array}$ & No. & $\begin{array}{l}\text { Per } \\
\text { cent }\end{array}$ & No. & $\begin{array}{l}\text { Per } \\
\text { cent }\end{array}$ \\
\hline Total - - & 214 & 100 & 162 & 100 & 130 & 100 & 32 & 100 & 52 & 100 & 47 & 100 & 5 & 100 \\
\hline $\begin{array}{l}\text { Both parents born } \\
\text { in Kentucky - - }\end{array}$ & 104 & 48.6 & 87 & 53.0 & 72 & 55.4 & 15 & 46.8 & 17 & 32.6 & 15 & 31.9 & 2 & 40.0 \\
\hline $\begin{array}{l}\text { One parent born } \\
\text { in Kentucky - - }\end{array}$ & 25 & 11.7 & 23 & 14.0 & 18 & 13.9 & 5 & 15.7 & 2 & 3.9 & 1 & 2.1 & 1 & 20.0 \\
\hline $\begin{array}{l}\text { Parents born } \\
\text { elsewhere - - }\end{array}$ & 60 & 28.0 & 39 & 24.0 & 32 & 24.6 & 7 & 21.8 & 21 & 40.3 & 20 & 42.6 & 1 & 20.0 \\
\hline Birthplace unknown & 25 & 11.7 & 13 & 9.0 & 8 & 6.1 & 5 & 15.7 & 12 & 23.2 & 11 & 23.4 & 1 & 20.0 \\
\hline
\end{tabular}


Type of Community Background

Census definitions were used in recording the type of community in which a prisoner's f'amily had lived until he was approximately sixteen years old. "Urban" includes cities and other incorporated places having 2,500 inhabitants or more. "Rural-nonf'arm" includes villages, mine camps, unincorporated suburban communities, et cetera, with less than 2,500 persons; "Rural-Farm" includes all persons living on t'arms.

The qualitied interpretation to be given Table 6 arises not f'rom deliberate misstatements but t'rom the prisoner's ignorance of the exact size of the community in which he used to live, and the consequent necessity for the interviewer to interpret the answer in the light of all intormation given; even so this will produce serious error only in cases where the community is of borderline size. In general, if a prisoner said he was raised on a f'arm, he was put down as "rural-t"arm"; it he said he came from a mine camp, he was classed as "rural-non-1"arm", et cetera. of the 214 cases reporting on this point, IU' or 50 per cent, claim to be of "urban" background with 15 , or 35 per cent, from "rural-t"arm" areas and 31, or 15 per cent, trom "rural-non-t"arm", as shown in Table 6, page 33. More of the Negro group, 59.6 per cent, came trom an "urban" background than did the white group, 46.9 per cent. Table 6 shows a larger proportion of the white prisoners come from "rural-1"arm" areas, in comparison to the Negro prisoners. The racial distribution is about the same f'or "ruralnon-t'arm" areas. 
TABLE 6

NATIVITY BY RACE AND SEX

\begin{tabular}{|c|c|c|c|c|c|c|c|c|c|c|c|c|c|c|}
\hline \multirow{3}{*}{ Type of Community } & \multicolumn{2}{|c|}{ Total } & \multicolumn{6}{|c|}{$W$ h $i t e$} & \multicolumn{6}{|c|}{$N$ e g r o } \\
\hline & & & \multicolumn{2}{|c|}{ Total } & \multicolumn{2}{|c|}{ Male } & \multicolumn{2}{|c|}{ Female } & \multicolumn{2}{|c|}{ Total } & \multicolumn{2}{|c|}{ Malo } & \multicolumn{2}{|c|}{ Fema]e } \\
\hline & No. & $\begin{array}{l}\text { Per } \\
\text { cent }\end{array}$ & No. & $\begin{array}{l}\text { Per } \\
\text { cent }\end{array}$ & No. & $\begin{array}{l}\text { Per } \\
\text { cent }\end{array}$ & No. & $\begin{array}{l}\text { Per } \\
\text { cent }\end{array}$ & No. & $\begin{array}{l}\text { Per } \\
\text { cent }\end{array}$ & No. & $\begin{array}{l}\text { Per } \\
\text { cent }\end{array}$ & No. & $\begin{array}{l}\text { Per } \\
\text { cent }\end{array}$ \\
\hline Total - - & 214 & 100 & 162 & 100 & 130 & 100 & 32 & 100 & 52 & 100 & 47 & 100 & 5 & 100 \\
\hline Urban $-\ldots$ & 107 & 50.0 & 76 & 46.9 & 66 & 50.8 & 10 & 31.3 & 31 & 59.6 & 28 & 59.6 & 3 & 60.0 \\
\hline Rural - farm - - & 75 & 35.0 & 61 & 37.7 & 48 & 36.9 & 13 & 40.6 & 14 & 26.9 & 13 & 27.6 & 1 & 20.0 \\
\hline Rura1-non-farm - & 31 & 15.0 & 24 & 14.8 & 16 & 12.3 & 8 & 25.0 & 7 & 13.5 & 6 & 12.8 & 1 & 20.0 \\
\hline Unknown - - - & 1 & - & 1 & 0.6 & - & - & 1 & 3.1 & - & - & - & - & - & - \\
\hline
\end{tabular}


Figure 1, page 35, shows the distribution by county of the 146 prisoners born in Kentucky, 68.2 per cent of the entire group studied. F'ifty-two of the 146 prisoners born in Kentucky, or 35.6 per cent, were born in Jef'terson County. I Of the 130 white males in the total study group, 94 or 72.3 per cent, were born in Kentucky as compared to 72 or 55.4 per cent of their parents who were born in Kentucky. ${ }^{2}$ of' the 32 white t'emales, 23 or 71.9 per cent were born in Kentucky as compared to 15 , or 46.8 per cent, of their parents who were born in Kentucky! Ot the total 52 Negroes, 29 or 55.8 per cent were born in Kentucky, as compared to 17 , or 32.6 per cent, of their parents who were born in the state. The majority of the prisoners who gave Kentucky as their birthplace were born in the West Central Section of the state.

\section{Marital status}

Information on the marital status of the group, presented in Table \%, page 36 , is based on statements made at the time of the interviews. I'he number of single prisoners is probably exaggerated, and the number of separated cases too small. Ot the total 177 male prisoners, '15 or 42.4 per cent claim never to have been married, which, considering the average age of the group $(38)^{3}$, is a high figure.

About 11 per cent of the group had been married but are now separated, and 21 per cent are divorced, making 32 per cent who

\footnotetext{
1 Appendix D. p. '/8, List and number of prisoners born in Kentucky, by county•

2 supra, Table 5, p. 31

3 Infra, Table $9, \mathrm{p} .41$
} 
NUMBer oF PRISONERS BORN IN KENTUCKY, BY COUNTY *



* Based on the total of 146 prisoners born in Kentucky, 68.2 per cent of the total group. 
TABLE 7

MARITAL STATUS BY RACE AND SEX

\begin{tabular}{|c|c|c|c|c|c|c|c|c|c|c|c|c|c|c|}
\hline \multirow{3}{*}{ Marital Status } & \multirow{2}{*}{\multicolumn{2}{|c|}{ Total }} & \multicolumn{6}{|c|}{$W h i t e$} & \multicolumn{6}{|c|}{$N \in g r o$} \\
\hline & & & \multicolumn{2}{|c|}{ Total } & \multicolumn{2}{|c|}{ Male } & \multicolumn{2}{|c|}{ Female } & \multicolumn{2}{|c|}{ Total } & \multicolumn{2}{|c|}{ Male } & \multicolumn{2}{|c|}{ Female } \\
\hline & No. & $\begin{array}{l}\text { Per } \\
\text { cent }\end{array}$ & No. & $\begin{array}{l}\text { Per } \\
\text { cent }\end{array}$ & No. & $\begin{array}{l}\text { Per } \\
\text { cent }\end{array}$ & No. & $\begin{array}{l}\text { Per } \\
\text { cent }\end{array}$ & No. & $\begin{array}{l}\text { Per } \\
\text { cent }\end{array}$ & No. & $\begin{array}{l}\text { Per } \\
\text { cent }\end{array}$ & No. & $\begin{array}{l}\text { Per } \\
\text { cent }\end{array}$ \\
\hline Total - - & 214 & 100 & 162 & 100 & 130 & 100 & 32 & 100 & 52 & 100 & 47 & 100 & 5 & 100 \\
\hline Single - - - & 79 & 36.9 & 57 & 35.2 & 55 & 42.3 & 2 & 6.2 & 22 & 42.3 & 20 & 42.6 & 2 & 40.0 \\
\hline Divorced - - - & 45 & 21.0 & 42 & 26.0 & 33 & 25.4 & 9 & 28.2 & 3 & 5.8 & 3 & 6.4 & - & - \\
\hline Married $--\cdots$ & 36 & 16.8 & 21 & 13.0 & 18 & 13.8 & 3 & 9.4 & 15 & 28.8 & 13 & 27.6 & 2 & 40.0 \\
\hline Widow or widower - & 26 & 12.1 & 23 & $14 \cdot 2$ & 15 & 11.6 & 8 & 25.0 & 3 & 5.8 & 3 & 6.4 & - & - \\
\hline Separated $--\cdots$ & 24 & 11.2 & 17 & 10.4 & 9 & 6.9 & 8 & 25.0 & 7 & 13.4 & 7 & 14.9 & - & - \\
\hline Common Law - - - & 4 & 2.0 & 2 & 1.2 & - & - & 2 & 6.2 & 2 & 3.9 & 1 & 2.1 & 1 & 20.0 \\
\hline
\end{tabular}


have not achieved a successtul marital adjustment. Only a small proportion ( 16.8 per cent) of the Workhouse group have any marital responsibilities or (by interence) any home ties.

\section{Number of Dependents}

With the lack of home ties, it is not significant that the inmates studied list f'ew dependents. Again, the intormation is based on the statements of the prisoners. Verfication was not made through tiield investigations. Furthermore, the question of defining a dependent is not simple, since actual dependency is one thing, and legal dependency another. The standard used in the study was to include the following as "adult dependents": (1) children 16 and under 21 who are not supporting themselves, (2) parents (no matter where they are located) who on the social history sheet are classed as dependents, (3) the man's wite, whether or not she supports herselt in whole or in part and whether or not she is separated from him. In cases of divorce, the former wite was excluded, and so were children over 21 and siblings and other blood relations unless the social history definitely indicates that the man contirbutes to their support. "Minor dependents" were detined to include children under 16 and exclude siblings and other blood relation under 16. The male prisoners and temale prisoners should not be compared on the subject of adult dependents, since a man's wife was reported as a dependent, while a woman's husband was not so counted.

There is some indication from Social Service Exchange registrations that the figures given in Table 8 , page 38 , are pro- 
TABLE 8

TYPE OF DEPENDENTS BY RACE AND SEX

\begin{tabular}{|c|c|c|c|c|c|c|c|c|c|c|c|c|c|c|}
\hline \multirow{3}{*}{ Dependents } & \multirow{2}{*}{\multicolumn{2}{|c|}{ Total }} & \multicolumn{6}{|c|}{ Whito } & \multicolumn{6}{|c|}{$N \in g r o$} \\
\hline & & & \multicolumn{2}{|c|}{ Total } & \multicolumn{2}{|c|}{ Male } & \multicolumn{2}{|c|}{ Female } & \multicolumn{2}{|c|}{ Total } & \multicolumn{2}{|c|}{ Male } & \multicolumn{2}{|c|}{ Female } \\
\hline & No. & $\begin{array}{l}\text { Per } \\
\text { cent }\end{array}$ & No. & $\begin{array}{l}\text { Per } \\
\text { cent }\end{array}$ & No. & $\begin{array}{l}\text { Per } \\
\text { cent }\end{array}$ & No. & $\begin{array}{l}\text { Per } \\
\text { cent }\end{array}$ & No. & $\begin{array}{l}\text { Per } \\
\text { cent }\end{array}$ & No. & $\begin{array}{l}\text { Per } \\
\text { cent }\end{array}$ & No. & $\begin{array}{l}\text { Per } \\
\text { cent }\end{array}$ \\
\hline Total -- & 214 & 100 & 162 & 100 & 130 & 100 & 32 & 100 & 52 & 100 & 47 & 100 & 5 & 100 \\
\hline No dependents - - & 139 & 65.0 & 116 & 71.5 & 85 & 65.4 & 31 & 96.9 & 23 & 44.2 & 19 & 40.4 & 4 & 80.0 \\
\hline Minor and adult - & 27 & 12.6 & 16 & 9.9 & 16 & 12.3 & - & - & 11 & 21.2 & 11 & 23.4 & - & - \\
\hline Adult only - - - & 25 & 11.7 & 15 & 9.3 & 15 & 11.5 & - & - & 10 & 19.2 & 9 & 19.2 & 1 & 20.0 \\
\hline Minor only - - & 23 & 10.7 & 15 & 9.3 & 14 & 10.8 & 1 & 3.1 & 8 & 15.4 & 8 & 17.0 & - & - \\
\hline
\end{tabular}


bebly underestimates. Sixty-fitre per cent of the group reported no dependents while 12.6 per cent claimed both minor and adult dependents and 11.7 per cent and 10.7 per cent, respectively, listed adult and minor dependents only. Of the 32 white female prisoners, 31 or 96.9 per cent, reported no dependents. While 11 of the female prisoners reported they had children under sixteen, they did not list them as dependents. Most of the women claimed their children were living with maternal or paternal grandparents and that they were not responsible for their support. Throughout, the figures indicate that the Negroes are more likely than the whites to have persons dependent upon them for support. The Negro male prisoners listed the largest number of dependents ( 1.8 persons per prisoner). The average number of dependents for the entire group is less than one per person $(.8)$. 
CHAPTHR $V$

PERSONAL CHARACTERISTICS

The three tables in this chapter contain the bulk of information on the social history of those interviewed. The dit'terent items vary in reliability, and supplementary intormation has been used whenever possible.

\section{Age}

For age there were three sources of information - the interview, police records, and Social Service Exchange records. In other woras, it was possible to see whether or not the prisonseos told the same story to three different sources. One Negro male misrepresented his age by stating that he was 18, after commitment it was learned that he was 16 , and his case was transt'erred to Juvenile Court.

Table 9, page 41, shows the age range to be trom 16 to 70 years. Only 4.2 per cent of the group studied were under 20 years oi age, while 81.5 per cent were in the age range 21 to 50 years. The largest group in the 21 to 50 years range was the 31.3 per cent falling in the 31 to 40 years class.

Of the white group, 27.8 per cent $f^{\prime} e l l$ in the 17 to 30 years range, as compared to 40.3 per cent for the Negro group in that range. The white group shows 72.2 per cent in the 31 years and orer age group, in comparison with 57.8 per cent for the Negroes in that range.

The average age for the entire group was 37 years. The 
TABLE 9

AGE BY RACE AND SEX




average age for the white male was 38 years and for the Negro male was 38 years, while the average age for the white female was 34 and the average age for the Negro I'emale was 27.

\section{Sex and Race}

Table 10, below, shows that there is an unequal distribution of sex by race. 177 of the 214 prisoners were males and 3 't were I'emales, which is a ratio of almost 5 to 1 . There were about is times as many white males as Negro males in the group. The racial distribution for the entire group studied was 162 or 75.1 per cent white and 52 or 24.3 per cent Negro.

of the 162 white prisoners interviewed, 130 , or about 80 per cent, were males and 32 , or about 20 pe $r$ cent, were t'emales: Ot the 52 Negro prisoners, 47 , or about 90 per cent, were males, and 5, or about 10 per cent, were temales. The percentage of Negro f'emales to Negro males was about halt that of white t'emales to white males.

\section{TABLE IU}

SEX BY RACE

\begin{tabular}{l|c|c|c|c|c|c}
\hline \multirow{2}{*}{ Sex } & \multicolumn{2}{|r|}{ Total } & \multicolumn{2}{|c|}{ White } & \multicolumn{2}{|c}{ Negro } \\
\cline { 2 - 7 } & No. & $\begin{array}{l}\text { Per } \\
\text { cent }\end{array}$ & No. & $\begin{array}{l}\text { Per } \\
\text { cent }\end{array}$ & No. & $\begin{array}{l}\text { Per } \\
\text { cent }\end{array}$ \\
\hline Total - - & 214 & 100 & 162 & 100 & 52 & 100 \\
\hline Male - - - - & 177 & 82.7 & 130 & 80.2 & $4 \%$ & 90.4 \\
\hline
\end{tabular}


Obvious Physical Defects

Table 11, page 44, shows that of the total 214 prisoners, only 26 or 12 per cent had obvious physical defects, i.e. those physical defects readily apparent to the interviewers. Although it can be said that the physical defects listed may be a factor in the maladjustment of the individual, they cannot be called a major cause, since 88 per cent of the prisoners did not appear to be physically handicapped. The physical handicaps were confined to the male prisoners, and were about equally distributed between white persons and Negroes. It is to be assumed that there were physical defects which were not apparent, and which may have been a factor in the prisoner's commitment. Medical examinations are not given routinely to prisoners admitted to the Workhouse. 
TABLE 11

OBVIOUS PHYSICAL DEFECTS OBSERVED BY RACE AND SEX

\begin{tabular}{|c|c|c|c|c|c|c|c|c|c|c|c|c|c|c|}
\hline \multirow{3}{*}{ Defects } & \multirow{2}{*}{\multicolumn{2}{|c|}{ Total }} & \multicolumn{6}{|c|}{$W \mathrm{~h} \perp \mathrm{te}$} & \multicolumn{6}{|c|}{$N$ e $g r o$} \\
\hline & & & \multicolumn{2}{|c|}{ Total } & \multicolumn{2}{|c|}{ Male } & \multicolumn{2}{|c|}{ Female } & \multicolumn{2}{|c|}{ Total } & \multicolumn{2}{|c|}{ Male } & \multicolumn{2}{|c|}{ Female } \\
\hline & No. & $\begin{array}{l}\text { Per } \\
\text { cent }\end{array}$ & No. & $\begin{array}{l}\text { Per } \\
\text { cent }\end{array}$ & No. & $\begin{array}{l}\text { Per } \\
\text { cent }\end{array}$ & No. & $\begin{array}{l}\text { Per } \\
\text { cent }\end{array}$ & No. & $\begin{array}{l}\text { Per } \\
\text { cent }\end{array}$ & No. & $\begin{array}{l}\text { Per } \\
\text { cent }\end{array}$ & No. & $\begin{array}{l}\text { Per } \\
\text { cent }\end{array}$ \\
\hline Total - - - & 214 & 100 & 162 & 100 & 130 & 100 & 32 & 100 & 52 & 100 & 47 & 100 & 5 & 100 \\
\hline None $-\ldots-\ldots$ & 188 & 87.9 & 146 & 90.1 & 115 & 88.8 & 31 & 96.9 & 42 & 80.8 & 37 & 78.7 & 5 & 100 \\
\hline Walking with Iimp - & 8 & 3.7 & 4 & 2.5 & 4 & 3.1 & - & - & 4 & 7.6 & 4 & 8.5 & - & - \\
\hline Blind in one eye - - & 5 & 2.4 & 3 & 1.9 & 3 & 2.3 & - & $\rightarrow$ & 2 & 3.9 & 2 & 4.3 & - & - \\
\hline Use of arm 1mpaired & 3 & 1.4 & 3 & 1.9 & 3 & 2.3 & - & - & - & - & - & - & - & - \\
\hline Hard of hearing - - & 2 & 1.0 & 2 & 1.2 & 1 & 0.7 & 1 & 3.1 & - & - & - & - & - & - \\
\hline Loss of one $J \in g-$ & 2 & 1.0 & 1 & 0.6 & 1 & 0.7 & - & - & 1 & 1.9 & 1 & 2.1 & - & -2 \\
\hline Facial scars - - - & 2 & 1.0 & - & - & - & - & - & - & 2 & 3.9 & 2 & $4 \cdot 3$ & - & - \\
\hline Loss of both Jegs - & 1 & 0.4 & - & - & - & - & - & - & 1 & 1.9 & 1 & 2.1 & - & - \\
\hline Hunchback - - - - & 1 & 0.4 & 1 & 0.6 & 1 & 0.7 & - & - & - & - & - & - & - & - \\
\hline $\begin{array}{l}\text { Paralysis of left } \\
\text { side }----(--\end{array}$ & 1 & 0.4 & 1 & 0.6 & 1 & 0.7 & - & - & - & - & - & - & - & - \\
\hline Fractured hip - - - & 1 & 0.4 & 1 & 0.6 & 1 & 0.7 & - & - & - & - & - & - & - & - \\
\hline
\end{tabular}


CHAPTER VI

PERSONAL BACHGROUND

Education

Information concerning the education of the group was based on the prisoner's own statements, and was not verified. Table 12, page 46, shows that approximately 98 per cent or 210 of the total group of 214 prisoners had some amount of schooling. The average schooling for the entire group was 8 years. of the total group 116 prisoners, 54.2 per cent, ranged between a 7 th and 9 th grade education. Of this group 55.4 per cent of the 130 white males, and 65.6 per cent of the 32 white females ranged from the 7 th to the 9 th grade, while 44.6 per cent of the 47 Negro males and 2 of the 5 Negro females also finished in the range from the 7 th to the 9 th grade. Of the total group, 40 or 18.6 per cent attended school beyond the 9 th grade. The 2 college graduates in the group were Negro males. Of the 4 prisoners listed as having no education, 2 admitted never attending school and 2 did not remember.

\section{Age on Leaving School}

The intormation on age of leaving school was obtained t'rom the prisoner's own statements, which cannot be assumed to be entirely correct due to the length of time some of the prisoners have been out of' school.

Table 13, page 47, indicates that about 71 per cent of the total group left school between the ages of 14 and 18 years. In 
TABLE 12

STATED SCHOOL GRADE COMPTETED BY RACE AND SEX

\begin{tabular}{|c|c|c|c|c|c|c|c|c|c|c|c|c|c|c|}
\hline \multirow{3}{*}{$\begin{array}{l}\text { School Grade } \\
\text { Completed }\end{array}$} & \multirow{2}{*}{\multicolumn{2}{|c|}{ Total }} & \multicolumn{6}{|c|}{$\mathrm{wh} i \mathrm{te}$} & \multicolumn{6}{|c|}{$N \in g r o$} \\
\hline & & & \multicolumn{2}{|c|}{ Total } & \multicolumn{2}{|c|}{$\mathrm{Ma} . \mathrm{e}$} & \multicolumn{2}{|c|}{ Female } & \multicolumn{2}{|c|}{ Total } & \multicolumn{2}{|c|}{ Maje } & \multicolumn{2}{|c|}{ Female } \\
\hline & No. & $\begin{array}{l}\text { Per } \\
\text { cent }\end{array}$ & No. & $\begin{array}{l}\text { Per } \\
\text { cent }\end{array}$ & No. & $\begin{array}{l}\text { Per } \\
\text { cent }\end{array}$ & No. & $\begin{array}{l}\text { Per } \\
\text { cent }\end{array}$ & No. & $\begin{array}{l}\text { Per } \\
\text { cent }\end{array}$ & No. & $\begin{array}{l}\text { Per } \\
\text { cent }\end{array}$ & No. & $\begin{array}{l}\text { Per } \\
\text { cent }\end{array}$ \\
\hline None $-\ldots-\ldots$ & 4 & 2.0 & 1 & 0.6 & - & - & 1 & 3.1 & 3 & 5.8 & 3 & 6.4 & - & $m$ \\
\hline 1 to $3-\cdots \cdots$ & 13 & 6.1 & 10 & 6.2 & 8 & 6.1 & 2 & 6.3 & 3 & 5.8 & 3 & 6.4 & $\infty$ & - \\
\hline 4 to $6-\cdots \cdots$ & 41 & 19.1 & 32 & 19.8 & 27 & 20.8 & 5 & 15.6 & 9 & 17.3 & 8 & 17.0 & 1 & 20.0 \\
\hline 7 to $9-\cdots \cdots$ & 116 & 54.2 & 93 & 57.4 & 72 & 55.4 & 21 & 65.6 & 23 & 44.2 & 21 & 44.6 & 2 & 40.0 \\
\hline 13 to $16 \cdots \cdots$ & 8 & 3.7 & 7 & $4 \cdot 3$ & 6 & 4.6 & 1 & 3.1 & 1 & 1.9 & - & - & 1 & 20.0 \\
\hline Over $16 \ldots-\ldots$ & 2 & 0.9 & - & - & - & $m$ & - & - & 2 & 3.9 & 2 & 4.3 & - & - \\
\hline $\begin{array}{l}\text { Average Schooling } \\
\text { (years) }\end{array}$ & & 8 & & 8 & & 7 & & 8 & & 8 & & 8 & & 8 \\
\hline
\end{tabular}


TABLE 13

AGE OF LEAVING SCHOOI, BY RACE AND SEX

\begin{tabular}{|c|c|c|c|c|c|c|c|c|c|c|c|c|c|c|}
\hline \multirow{3}{*}{ Age } & \multicolumn{2}{|c|}{ Total } & \multicolumn{6}{|c|}{$W$ bi $t e$} & \multicolumn{6}{|c|}{$N \in g r o$} \\
\hline & \multicolumn{2}{|l|}{. } & \multicolumn{2}{|c|}{ Total } & \multicolumn{2}{|c|}{ Male } & \multicolumn{2}{|c|}{ Female } & \multicolumn{2}{|c|}{ Total } & \multicolumn{2}{|c|}{ Male } & \multicolumn{2}{|c|}{ Fema]e } \\
\hline & No. & $\begin{array}{l}\text { Per } \\
\text { cent }\end{array}$ & No. & $\begin{array}{l}\text { Per } \\
\text { cent }\end{array}$ & No. & $\begin{array}{l}\text { Per } \\
\text { cent }\end{array}$ & No. & $\begin{array}{l}\text { Per } \\
\text { cent }\end{array}$ & No. & $\begin{array}{l}\text { Per } \\
\text { cent }\end{array}$ & No. & $\begin{array}{l}\text { Per } \\
\text { cent }\end{array}$ & No. & $\begin{array}{l}\text { Per } \\
\text { cent }\end{array}$ \\
\hline Total - - & 214 & 100 & 162 & 100 & 130 & 100 & 32 & 100 & 52 & 100 & 47 & 100 & 5 & 100 \\
\hline Never attended school & 2 & 0.9 & 1 & 0.6 & - & - & 1 & 3.1 & 1 & 1.9 & 1 & 2.1 & - & - \\
\hline 9 to 13 years - & 33 & 15.5 & 25 & 15.4 & 17 & 13.1 & 8 & $25.0^{\circ}$ & 8 & 15.4 & 7 & $14 \cdot 9$ & 1 & 20.0 \\
\hline 14 to 18 years - - - & 153 & 71.5 & 121 & 74.7 & 101 & 77.7 & 20 & 62.5 & 32 & 61.5 & 29 & 61.7 & 3 & 60.0 \\
\hline 19 to 23 years - - - & 16 & 7.5 & 12 & 7.4 & 9 & 6.9 & 3 & 9.4 & 4 & 7.7 & 3 & 6.4 & 1 & 20.0 \\
\hline 24 to 28 years - - - & 2 & 0.9 & - & - & - & - & - & - & 2 & 3.9 & 2 & $4 \cdot 3$ & - & - \\
\hline Unknown $--\cdots$ & 7 & 3.3 & 3 & 1.9 & 3 & 2.3 & - & - & 4 & 7.7 & 4 & 8.5 & - & - \\
\hline $\begin{array}{l}\text { Attending school } \\
\text { at arrest }\end{array}$ & 1 & 0.4 & - & - & - & - & - & - & 1 & 1.9 & 1 & 2.1 & - & $\rightarrow$ \\
\hline
\end{tabular}


This age group, aoout 75 per cent were white and about 62 per cent Negro. only about 8 , per cent of the total group attended school atter they reached the age of 18. The compulsory school law may well have been a tactor in keeping some of the prisoners in school until the age of 16 .

The average age of the entire group on leaving school was about 16, while the average grade completed was the $8 \mathrm{th} .1$ Ihis retardation can not be entirely attributed to the prisoners' lack of mental ability because, in many instances, the lack of opportunity probably was a contributing factor.

\section{Reason Given Hor Leaving School}

Intormation on the reason for leaving school is based upon the prisoners' statements. It is believed that the reason given I'or leaving school tends to be more accurate than the age given on leaving school. The f'igures may be somewhat exaggerated when they show that 66.3 per cent of those who attended school left to go to work, as is shown in Table 14, page 49. Nevertheless, the majority did leave to seek employment. OI' the 130 white male prisoners, 73.8 per cent quit to seek employment, as compared to 31.3 per cent of the white t'emales.

Among the 52 Negro prisoners, 69.2 per cent left to seek employment. Of the 47 Negro males, 12.3 per cent quit to go to work as compared to 40 per cent of the Negro t'emales. Although 11.' per cent gave "disliked school" as their reason for quitting school, it should be noted that there were several reasons for

\footnotetext{
1 Supra, 'Pable 12, p. 46
} 
TABT:E 14

REASON GIVEN FOR LEAVING SCHOOL BY RACE AND SEX

\begin{tabular}{|c|c|c|c|c|c|c|c|c|c|c|c|c|c|c|}
\hline \multirow{3}{*}{$\begin{array}{l}\text { Reason for } \\
\text { leaving school }\end{array}$} & \multirow{2}{*}{\multicolumn{2}{|c|}{ Total }} & \multicolumn{6}{|c|}{ White } & \multicolumn{6}{|c|}{$\mathrm{Neg} r$} \\
\hline & & & \multicolumn{2}{|c|}{ Total } & \multicolumn{2}{|c|}{ Male } & \multicolumn{2}{|c|}{ Female } & \multicolumn{2}{|c|}{ Total } & \multicolumn{2}{|c|}{ Male } & \multicolumn{2}{|c|}{ Female } \\
\hline & No. & $\begin{array}{l}\text { Per } \\
\text { cent }\end{array}$ & No. & $\begin{array}{l}\text { Per } \\
\text { cent }\end{array}$ & No. & $\begin{array}{l}\text { Per } \\
\text { cent }\end{array}$ & No. & $\begin{array}{l}\text { Per } \\
\text { cent }\end{array}$ & No. & $\begin{array}{l}\text { Per } \\
\text { cent }\end{array}$ & No. & $\begin{array}{l}\text { Per } \\
\text { cent }\end{array}$ & No. & $\begin{array}{l}\text { Per } \\
\text { cent }\end{array}$ \\
\hline Total - - & 214 & 100 & 162 & 100 & 130 & 100 & 32 & 100 & 52 & 100 & 47 & 100 & 5 & 100 \\
\hline Emplcyment _ - - & 142 & 66.3 & 106 & 65.4 & 96 & 73.8 & 10 & 31.3 & 36 & 69.2 & 34 & 72.3 & 2 & 40.0 \\
\hline Disliked school - - & 25 & 11.7 & 21 & 12.4 & 15 & 11.6 & 6 & 18.8 & 4 & 7.6 & 3 & 6.4 & 1 & 20.0 \\
\hline Graduated - - - - & 9 & 4.2 & 6 & 3.9 & 5 & 3.9 & 1 & 3.1 & 3 & 5.8 & 3 & 6.4 & - & - \\
\hline Military service - - & 9 & 4.2 & 9 & 5.6 & 9 & 6.9 & - & - & - & - & - & - & - & - \\
\hline Marriage $-\cdots$ & 8 & 3.7 & 6 & 3.9 & - & - & 6 & 18.7 & 2 & 3.9 & $I$ & 2.1 & 1 & 20.0 \\
\hline Institutionalized -- & 4 & 2.0 & 3 & 2.0 & 2 & 1.5 & 1 & 3.1 & 1 & 1.9 & 1 & 2.1 & - & - \\
\hline Never went to school & 3 & 1.4 & - & - & - & - & - & - & 3 & 5.8 & 3 & 6.4 & - & - \\
\hline Other $\ldots \ldots$ & 14 & 6.5 & 11 & 6.8 & 3 & 2.3 & 8 & 25.0 & 3 & 5.8 & 2 & 4.3 & 1 & 20.0 \\
\hline
\end{tabular}


disliking school such as, lack of money or clothing, inability to learn, or inability to conform with school regulations, et cetera. Ot the total group, only 9 white males quit school to enter military service. None of the white males gave marriage as the reason for leaving school, while 7 temales (six white and one Negro) gave marriage as the reason tor leaving; one Negro male also gave marriage as a reason t'or leaving.

Listed under "other" are scattered reasons for leaving

school such as: pregnancy, death or separation of parents, expelled, illness, no reason, and physical handicaps.

\section{Age On Leaving Home}

Age at time of a particular event is not easily remembered accurately after a lapse of 15 or 20 years, so the data on age of leaving the parental home, Table 15, page 51, must be accepted on a qualitied basis.

There are no signiticant racial differences in the age on leaving home. Ot' the entire group, 46.3 per cent let't home between the ages of 16 to 21 , and 8.8 per cent of the prisoners have never leit nome. 'lable 15 shows that 61.8 per cent of the entire group lef't home betore they were 2I. The t'emales were more likely to leave home at an earlier age than the males. The average age on leaving home for the entire group was 19. The average age for the white and Negro male prisoners was 20, while the Negro temales lef:t, on the average, when they were 19, and the white temales let't when they were 1\%. The majority of the women gave marriage as their reason tor leaving home, while the majority of the men let't home 
TABIE 15

AGE ON LEAVING HOME BY RACE AND SEX

\begin{tabular}{|c|c|c|c|c|c|c|c|c|c|c|c|c|c|c|}
\hline \multirow{3}{*}{ Age } & \multicolumn{2}{|c|}{ Total } & \multicolumn{6}{|c|}{ White } & \multicolumn{6}{|c|}{$N$ e $g r o$} \\
\hline & & & \multicolumn{2}{|c|}{ Total } & \multicolumn{2}{|c|}{ Male } & \multicolumn{2}{|c|}{ Female } & \multicolumn{2}{|c|}{ Total } & \multicolumn{2}{|c|}{ Male } & \multicolumn{2}{|c|}{ Female } \\
\hline & No. & $\begin{array}{l}\text { Per } \\
\text { cent }\end{array}$ & No. & $\begin{array}{l}\text { Per } \\
\text { cent }\end{array}$ & No. & $\begin{array}{l}\text { Per } \\
\text { cent }\end{array}$ & No. & $\begin{array}{l}\text { Per } \\
\text { cent }\end{array}$ & No. & $\begin{array}{l}\text { Per } \\
\text { cent }\end{array}$ & No. & $\begin{array}{l}\text { Per } \\
\text { cent }\end{array}$ & No. & $\begin{array}{l}\text { Per } \\
\text { cent }\end{array}$ \\
\hline Total - - & 214 & 100 & 162 & 100 & 130 & 100 & 32 & 100 & 52 & 100 & 47 & 100 & 5 & 100 \\
\hline Unknown $-\ldots$ & 9 & 4.2 & 6 & 3.7 & 6 & 4.6 & - & - & 3 & 5.8 & 2 & $4 \cdot 3$ & 1 & 20.0 \\
\hline Less than 10 years - & 2 & 1.0 & 1 & 0.6 & 1 & 0.7 & - & - & 1 & 1.9 & 1 & 2.2 & - & - \\
\hline 10 to 15 years - & 3]. & 14.5 & 24 & 14.8 & 15 & 11.5 & 9 & 28.2 & 7 & 13.5 & 7 & 14.9 & - & - \\
\hline 16 to 21 years - & 99 & 46.3 & 77 & 47.5 & 56 & 43.1 & 21 & 65.6 & 22 & 42.3 & 19 & 40.4 & 3 & 60.0 \\
\hline Over 21 years $-\ldots$ & 54 & 25.2 & 40 & 24.7 & 38 & 29.3 & 2 & 6.2 & 14 & 26.9 & 13 & 27.6 & 1 & 20.0 \\
\hline Never left home $-\ldots$ & 19 & 8.8 & 14 & 8.7 & 14 & 10.8 & - & - & 5 & 9.6 & 5 & 10.6 & - & $\rightarrow$ \\
\hline
\end{tabular}


to seek employment.

\section{Residence in City}

Table 16, page 53, and Figure 2, page 54, throw some light on the extent to which the City of Louisville produces its own prison population, and on the city areas from which delinquents come. All the prisoners were asked where they lived and how long they had been in Louisville. Both points were checked with the Social Service lixchange registrations, but an accurate check on addresses proved impossible because too of'ten a period of several years intervened between the date of commitment and the date when the agency knew the case. It was, however, possible by making allowance for this to compare the two sources of information for the time spent by the prisoner in the City.

Table 16 shows that 10 prisoners, or 4.7 per cent were admittedly transients-floaters who dritt in and out of the city. A greater proportion of white persons had been in the city one year or less or were transients than those in the ljegro group, 28.4 per cent as compared to 13.5 per cent. Considering as permanent residents all those who have lived in the city more than five years, it was found that 65.1 per cent fell in that category. A very substantial proportion, 25.7 per cent, claim to have lived in Louisville all their lives. Clearly the adult delinquency probIem in the City is not primarily the problem of the trensient person but something rooted in the city's own life.

It is a well established fact that in the average American 
TABLE 16

LENGTH OF TIME IN CITY BEFORE COMMITMENT BY RACE AND SEX

\begin{tabular}{|c|c|c|c|c|c|c|c|c|c|c|c|c|c|c|}
\hline \multirow{3}{*}{ Time in City } & \multirow{2}{*}{\multicolumn{2}{|c|}{ Total }} & \multicolumn{6}{|c|}{$W h i t e$} & \multicolumn{6}{|c|}{$N$ e $g \circ$} \\
\hline & & & \multicolumn{2}{|c|}{ Total } & \multicolumn{2}{|c|}{ Male } & \multicolumn{2}{|c|}{ Female } & \multicolumn{2}{|c|}{ Total } & \multicolumn{2}{|c|}{ Male } & \multicolumn{2}{|c|}{ Female } \\
\hline & No. & $\begin{array}{l}\text { Per } \\
\text { cent }\end{array}$ & No. & $\begin{array}{l}\text { Per } \\
\text { cent }\end{array}$ & No. & $\begin{array}{l}\text { Per } \\
\text { cent }\end{array}$ & No. & $\begin{array}{l}\text { Per } \\
\text { cent }\end{array}$ & No. & $\begin{array}{l}\text { Per } \\
\text { cent }\end{array}$ & No. & $\begin{array}{l}\text { Per } \\
\text { cent }\end{array}$ & No. & $\begin{array}{l}\text { Per } \\
\text { cent }\end{array}$ \\
\hline Total - - & 214 & 100 & 162 & 100 & 130 & 100 & 32 & 100 & 52 & 100 & 47 & 100 & 5 & 100 \\
\hline Life $-\cdots--\cdots$ & 55 & 25.7 & 42 & 25.9 & 36 & 27.7 & 6 & 18.8 & 13 & 25.0 & 12 & 25.5 & 7 & 20.0 \\
\hline $\begin{array}{l}5 \text { years and less } \\
\text { than life }----\end{array}$ & 80 & 37.4 & 58 & 35.8 & 42 & 32.3 & 16 & 50.0 & 22 & 42.3 & 21 & 44.7 & 1 & 20.0 \\
\hline One year to 5 years - & 26 & 12.1 & 16 & 9.9 & 12 & 9.2 & 4 & 12.5 & 10 & 19.2 & 8 & 17.0 & 2 & 40.0 \\
\hline Less than one year - & 43 & 20.1 & 38 & 23.5 & 36 & 27.7 & 2 & 6.2 & 5 & 9.6 & 4 & 8.5 & 1 & 20.0 \\
\hline
\end{tabular}




\section{LOUJSYJLLE}

Census Tract Map

FIGURE 2

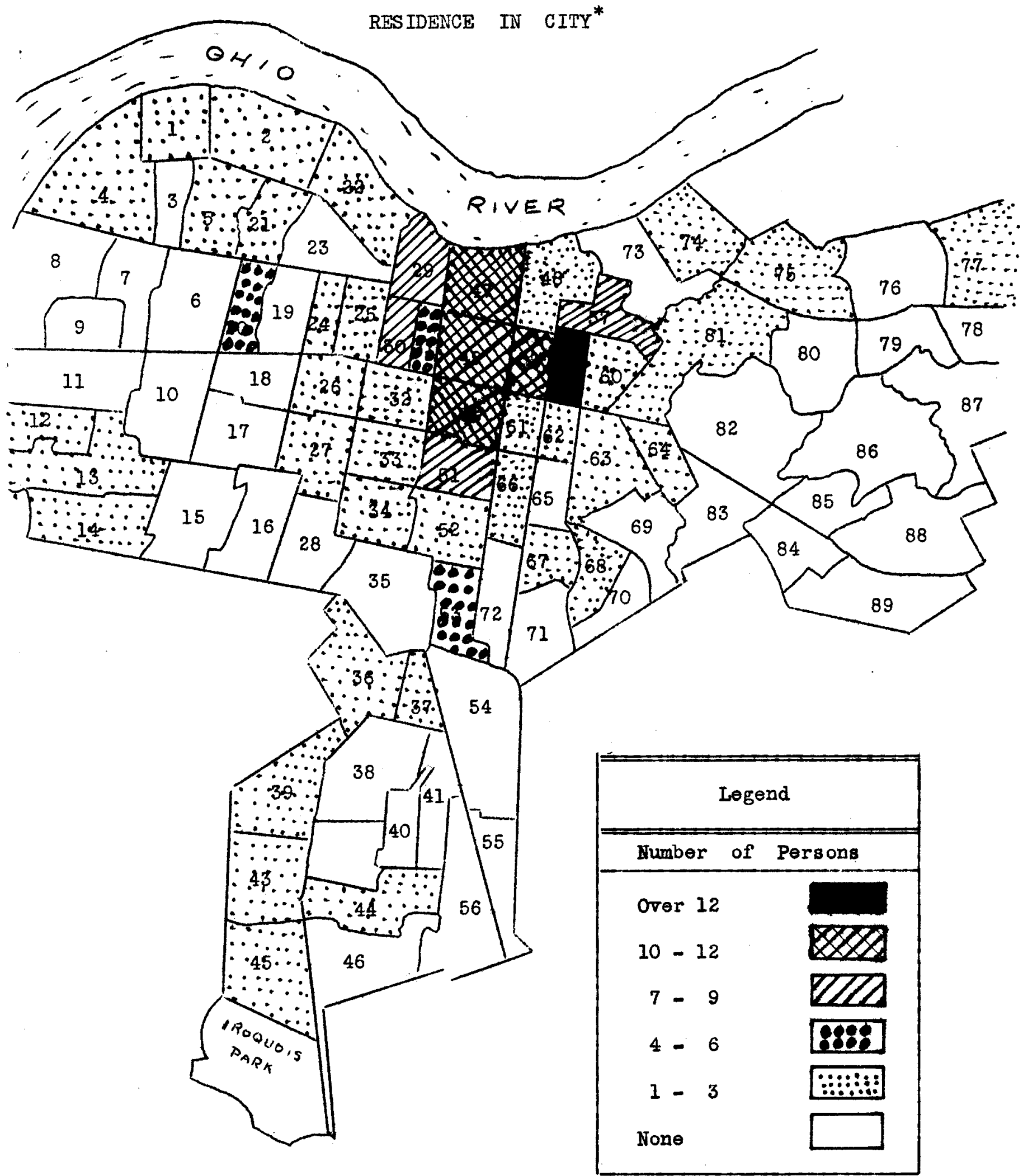

* Based on the 163 prisoners residing in Louisville, 76.1 per cent of the total group. 
city certain congested slum areas bordering on industrial or commerical sections are the regions which breed and shelter deIinquency, and Louisville is no exception. These areas are characterized by high rates of juvenile delinquency and adult crime, poor housing, high incidence of illness, and low income levels.

Figure 2, page 54, gives a picture oi the way in which the 160 prisoners living in Louisville at the time of arrest were congested in certain sections of Louisville. 1

Of the 163 prisoners, 54 came from the portion of Louisvilie which is the section of alley dwellings, flophouses, missions and cheap rooming houses. This includes the much publicized "Haymarket Area". The expensive residential areas of the city are not represented in the rates portrayed in Figure 2. The map shows that most of the prisoners come from low income and deteriorated areas of the city.

$$
\text { Religion }
$$

Table 17, page 56, shows that 165 of the 214 prisoners studied, or 77.1 per cent, stated that their religious atiiliation was Protestant. A total of 41 prisoners, or 19.1 per cent, listed their religion as Catholic.

There is no marked dititerence in the percentage of whites and Negroes who belong to a Protestant Church. Thirty-seven or 22.8 per cent of the 162 white prisoners said they belonged to

1 See Appendix C, page 77, Prisoners Living in Louisvilile by Census Tract, for a tabulation of the residence of the prisoners by census tract. 
the Catholic Church, while only 4 or 7.6 per cent of the 52 Negroes said they were Catholic.

only 8 prisoners, or 3.8 per cent of the group, fall in the "other" category, composed of those who stated they were not connected in any way with a religious organization.

TABLE 17

RELIGION BY RACE

\begin{tabular}{r|r|r|r|r|r|r|}
\hline \multirow{2}{*}{ Religion } & \multicolumn{2}{|r|}{ Total } & & \multicolumn{2}{|c|}{ White } & \multicolumn{2}{|c|}{ Negro } \\
\cline { 2 - 7 } & No. & $\begin{array}{l}\text { Per } \\
\text { cent }\end{array}$ & No. & $\begin{array}{l}\text { Per } \\
\text { cent }\end{array}$ & No. & $\begin{array}{l}\text { Per } \\
\text { cent }\end{array}$ \\
\hline Total - - & 214 & 100 & 162 & 100 & 52 & 100 \\
\hline Protestant - - - & 166 & 77.1 & 121 & 74.7 & 44 & 84.7 \\
Catholic - - - & 41 & 19.1 & 37 & 22.8 & 4 & 7.6 \\
\hline
\end{tabular}

\section{Military Service}

Table 18, page 57, shows that 39.3 per cent of the 214 prisoners have had military service of some kind. None of the women prisoners reported having any military service. A total of 59 of the 177 male prisoners, or 33.3 per cent, had served in World War II. The extent to which the types of difficulties represented in the Workhouse commitment were factors in the rejection for military service of the 118 male prisoners who did not serve in World War II was not ascertained. Only 2 prisoners served in both World Wars, and 4 reported other military service. 
TABT F 18

MIIITARY SERVICE BY RACE AND SFX

\begin{tabular}{|c|c|c|c|c|c|c|c|c|c|c|c|c|c|c|}
\hline \multirow{3}{*}{ Military Service } & \multirow{2}{*}{\multicolumn{2}{|c|}{ Total }} & \multicolumn{6}{|c|}{$\mathbf{W}$ b $i t e$} & \multicolumn{6}{|c|}{$N \in g r o$} \\
\hline & & & \multicolumn{2}{|c|}{ Total } & \multicolumn{2}{|c|}{ Male } & \multicolumn{2}{|c|}{ Female } & \multicolumn{2}{|c|}{ Total } & \multicolumn{2}{|c|}{ Male } & \multicolumn{2}{|c|}{ Female } \\
\hline & No. & $\begin{array}{l}\text { Per } \\
\text { cent }\end{array}$ & No. & $\begin{array}{l}\text { Per } \\
\text { cent }\end{array}$ & No. & $\begin{array}{l}\text { Per } \\
\text { cent }\end{array}$ & No. & $\begin{array}{l}\text { Per } \\
\text { cent }\end{array}$ & No. & $\begin{array}{l}\text { Per } \\
\text { cent }\end{array}$ & No: & $\begin{array}{l}\text { Per } \\
\text { cent }\end{array}$ & No. & $\begin{array}{l}\text { Per } \\
\text { cent }\end{array}$ \\
\hline Total $\ldots$ & 214 & 100 & 162 & 100 & 130 & 100 & 32 & 100 & 52 & 100 & 47 & 100 & 5 & 100 \\
\hline No military service & 130 & 60.7 & 94 & 58.0 & 62 & 47.7 & 32 & 100 & 36 & 69.2 & 31 & 66.0 & 5 & 100 \\
\hline World War II - - & 57 & 26.6 & 43 & 26.6 & 43 & 33.2 & - & - & 14 & 26.9 & 14 & 29.7 & - & - \\
\hline World War I $-\ldots$ & 21 & 9.8 & 19 & 11.7 & 19 & 14.6 & - & - & 2 & 3.9 & 2 & $4 \cdot 3$ & - & - \\
\hline $\begin{array}{l}\text { Other military } \\
\text { service }----\end{array}$ & 4 & 2.0 & 4 & 2.5 & 4 & 3.1 & - & - & - & $m$ & - & - & - & - \\
\hline
\end{tabular}




\section{ECONOMIC BACKGROUND}

Three sources were used to obtain information regarding the economic background of the prisoners: (1) Kentucky state Employment Service registrations, (2) Social Service Exchange registrations, and (3) the prisoners own statement concerning means of support, trade, and employment status at time of arrest.

\section{Means of support}

Table 19, page 59, shows that 108, or 50.5 per cent of the group studied, gave employment as their means of support. Among the 130 white male prisoners, 68 or 52.3 per cent gave employment as their means of support. Only 4 or 12.5 per cent of the white f'emales listed employment as their means of support. Of the 47 Negro males, 33 or 70.3 per cent depend solely on employment as their means of support, and 5 of the 5 Negro females gave employment as their means of support.

"No visible means" of support is the next most trequent mentioned category listed for the prisoners. Of the total group, 45 or 21 per cent had no visible means of support. Ot the 162 white prisoners, 37 or 22.8 per cent had no visible means of support. of the 37 white prisoners having no visible means of support, 36 are white males. Of the total 52 Negro prisoners, 8 or 15.4 per cent have no visible means of support.

of the 19 prisoners claiming to be supported by their t'amily, 16 were white women. 
TABTE 19

MEANS OF SUPPORT BY RACE AND SEX

\begin{tabular}{|c|c|c|c|c|c|c|c|c|c|c|c|c|c|c|}
\hline \multirow{3}{*}{ Type of Support } & \multirow{2}{*}{\multicolumn{2}{|c|}{ Total }} & \multicolumn{6}{|c|}{$W h i t e$} & \multicolumn{6}{|c|}{$N \in g r o$} \\
\hline & & & \multicolumn{2}{|c|}{ Total } & \multicolumn{2}{|c|}{ Male } & \multicolumn{2}{|c|}{ Female } & \multicolumn{2}{|c|}{ Total } & \multicolumn{2}{|c|}{ Male } & \multicolumn{2}{|c|}{ Fema]e } \\
\hline & No. & $\begin{array}{l}\text { Per } \\
\text { cent }\end{array}$ & No. & $\begin{array}{l}\text { Per } \\
\text { cent }\end{array}$ & No. & $\begin{array}{l}\text { Per } \\
\text { cent }\end{array}$ & No. & $\begin{array}{l}\text { Per } \\
\text { cent }\end{array}$ & No. & $\begin{array}{l}\text { Per } \\
\text { cent }\end{array}$ & No. & $\begin{array}{l}\text { Per } \\
\text { cent }\end{array}$ & No. & $\begin{array}{l}\text { Per } \\
\text { cent }\end{array}$ \\
\hline Total - - - & 214 & 100 & 162 & 100 & 130 & 100 & 32 & 100 & 52 & 100 & 47 & 100 & 5 & 100 \\
\hline Employment - - - & 108 & 50.5 & 72 & $44 \cdot 4$ & 68 & 52.3 & 4 & 12.5 & 36 & 69.2 & 33 & 70.3 & 3 & 60.0 \\
\hline No visible means - & 45 & 21.0 & 37 & 22.8 & 36 & 27.7 & 1 & 3.1 & 8 & 15.4 & 8 & 17.0 & - & - \\
\hline Support by family - & 19 & 8.8 & 18 & 11.1 & 2 & 1.5 & 16 & 50.0 & $I$ & 1.9 & 1 & 2.1 & - & - \\
\hline Government benefits & 16 & 7.5 & 14 & 8.7 & 14 & 10.8 & - & - & 2 & 3.9 & 1 & 2.1 & 1 & 20.0 \\
\hline Prostitution $--\cdots$ & 10 & 4.7 & 9 & 5.6 & - & - & 9 & 28.2 & 1 & 1.9 & - & - & 1 & 20.0 \\
\hline $\begin{array}{l}\text { Employment plus } \\
\text { government benefits }\end{array}$ & 9 & 4.2 & 8 & 4.9 & 7 & 5.4 & 1 & 3.1 & 1 & 1.9 & 1 & 2.1 & - & - \\
\hline Pensions $-\ldots$ & 7 & 3.3 & 4 & 2.5 & 3 & 2.3 & 1 & 3.1 & 3 & 5.8 & 3 & 6.4 & - & - \\
\hline
\end{tabular}


Government benefits either totally or partially support 25 or 11.7 per cent of the total group. Retirement and disability pensions from private industries are the means of support of only 7 prisoners, or 3.3 por cent.

Trade

Since so many of the prisoners had claimed to have lett school in order to go to work, ${ }^{l}$ an efifort was made to ascertain what kinds of jobs they had been able to hold. The interviewers asked each prisoner for a briet employment history, with names and addresses of employers, approximate dates and description ot jobs. The questioning was more successfiul with prisoners who have had steady work with only a few employers. From the variety of data there was extracted that which appeared to be the prisoner's usual job in so tiar as he had one.

As shown in Table 20, page 61, the unskilled group is the largest single group represented, with 93 of the 214 prisoners, 43.5 per cent, claiming no occupational skill. The 52 prisoners, 24.5 per cent, who were classitied as skilled were those who had served a period of apprenticeship in their particular field. The 43 who were classed as semi-skilled, 20.1 per cent, were those whose job required a certain amount ot aptitude but no apprenticeship, such as truck drivers and carpenter helpers.

of the total group 87.9 per cent were classed as unskilled, skilled and semi-skilled. This group depends upon the range of occupations that are found in urban areas. Only 11, or 5.2 per 
TABIE 20

USUAL TRADE OR OCCUPATION BY RACE AND SEX




cent of the group claimed to be farmers. Listed under "other" are 8 white f'emales who gave prostitution as their occupation. The number who gave a military, clerical, or protessional vocational background was very small.

Employment Status at time of Arrest

While $8 \% . y$ per cent of the total group were classed as unskilled, skilled and semi-skilled, 1 Table 2l, page 63, shows that only 74, or 34.6 per cent, were employed at the time of arrest. Another 15.5 per cent, or 33, were unemployed less than a month. Ot the 162 white prisoners, 35.4 per cent of the males and 12.5 per cent of the Iemales were employed at the time of arrest. A greater pe rcentage of the Negro prisoners were employed at the time of arrest, 44.6 per cent of the males, and 3 of the 5 Negro t'emales.

The white temales made no pretense about their employment, 2

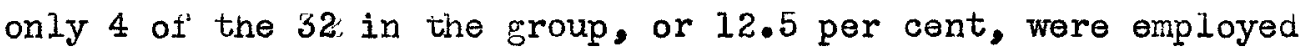
at the time of arrest, while 53.1 per cent had not been employed for 7 months or longer.

Of the 64.6 per cent white male prisoners who were unemployed at the time of arrest, 50.8 per cent had been unemployed less than six months, while 6.1 per cent had been unemployed for over I year and only 0.8 per cent had never been employed. A number of the unemployed prisoners are receiving Government benetits. 3

1 Supra, Table 20, p. 6I

2 Supra, lable 19, p. $5 y$

3 supra, Table 19, p. 59 
TABIE 21

STATED EMPLOYMENT STATUS AT TIME OF ARREST BY RACE AND SEX

\begin{tabular}{|c|c|c|c|c|c|c|c|c|c|c|c|c|c|c|}
\hline \multirow{3}{*}{ Employment Status } & \multirow{2}{*}{\multicolumn{2}{|c|}{ Total }} & \multicolumn{6}{|c|}{ Wh $\mathrm{i} t \mathrm{e}$} & \multicolumn{6}{|c|}{$N$ e g r o } \\
\hline & & & \multicolumn{2}{|c|}{ Total } & \multicolumn{2}{|c|}{ Male } & \multicolumn{2}{|c|}{ Female } & \multicolumn{2}{|c|}{ Total } & \multicolumn{2}{|c|}{ Male } & \multicolumn{2}{|c|}{ Female } \\
\hline & No. & $\begin{array}{l}\text { Per } \\
\text { cent }\end{array}$ & No. & $\begin{array}{l}\text { Per } \\
\text { cent }\end{array}$ & No. & $\begin{array}{l}\text { Per } \\
\text { cent }\end{array}$ & No. & $\begin{array}{l}\text { Per } \\
\text { cent }\end{array}$ & No. & $\begin{array}{l}\text { Per } \\
\text { cent }\end{array}$ & No. & $\begin{array}{l}\text { Per } \\
\text { cent }\end{array}$ & No. & $\begin{array}{l}\text { Per } \\
\text { cent }\end{array}$ \\
\hline Total - - & 214 & 100 & 162 & 100 & 130 & 100 & 32 & 100 & 52 & 100 & 47 & 100 & 5 & 100 \\
\hline $\begin{array}{l}\text { Fimployed at time } \\
\text { of arrest }-\ldots \\
\text { Unemployed at time } \\
\text { of arrest: }\end{array}$ & 74 & 34.6 & 50 & 30.9 & 46 & 35.4 & 4 & 12.5 & 24 & 46.1 & 21 & 44.6 & 3 & 60.0 \\
\hline Less than 1 month & 33 & 15.5 & 25 & $15 \cdot 4$ & 24 & 18.5 & 1 & 3.1 & 8 & 15.4 & 8 & 17.0 & - & - \\
\hline 1 to 6 months - & 67 & 31.3 & 52 & 32.1 & 42 & 32.3 & 10 & $31 \cdot 3$ & 15 & 28.8 & 14 & 29.7 & 1 & 20.0 \\
\hline 7 to 12 months - & 14 & 6.5 & 13 & 8.0 & 9 & 6.9 & 4 & 12.5 & 1 & 1.9 & 1 & 2.2 & - & $\rightarrow$ \\
\hline Over 12 months - - & 14 & 6.5 & 12 & 7.4 & 8 & 6.1 & 4 & 12.5 & 2 & 3.9 & 1 & 2.2 & 1 & 20.0 \\
\hline Never employed - - & 12 & 5.6 & 10 & 6.2 & 1 & 0.8 & 9 & 28.1 & 2 & 3.9 & 2 & $4 \cdot 3$ & - & - \\
\hline
\end{tabular}


Registration at Kentucky state Employment Service

While 34.6 per cent of the prisoners were employed at the time of arrest, ${ }^{\perp}$ Table 22 , page 65 , shows that 71.9 per cent, or 152 of the 214 prisoners interviewed, nad not been known to the Kentucky State Employment Service. Thls would indicate that the prisoners were either unaware of these services oftered in the community, or they f'ailed to take advantage of these services because of lack of interest or initiative.

of the 162 white prisoners, 77.2 per cent or 125 were not registered with the employment service, 75.4 of the white males and 84.3 of the females. Of the total 52 Negro prisoners, 55.7 per cent or 29 prisoners were not registered, 53.2 of the males and 4 of the 5 t'emales.

The prisoners who are registered with the Employment Service are divided into the "inactive" and "active" groups. The "active" includes those who have been known to the timployment service in the last 30 days from the date of arrest.

of the total group, 60 prisoners or 28.1 per cent, had registered with the Kentucky Employment Service; 16.4 per cent of the total group were inactive registrations and 11.7 per cent were active registrations. More of the Negro males were registered than the white males, 46.8 per cent as compared with 24.6 per cent. As Table 22 shows, 17.0 per cent of the Negro males were active registrants, while 13.1 per cent of the white males had active registrations. Ncne of the white or Negro females had active registrations. As a whole, the prisoners had failed to take advantage of the services. 
TABIE 22

RFGISTRATIONS WITH KENTUCKY STATE EMPIOYMENT SERVICE BY RACE AND SEX

\begin{tabular}{|c|c|c|c|c|c|c|c|c|c|c|c|c|c|c|}
\hline \multirow{3}{*}{ Registration Status } & \multirow{2}{*}{\multicolumn{2}{|c|}{ Total }} & \multicolumn{6}{|c|}{$w h i t e$} & \multicolumn{6}{|c|}{$\mathrm{N}$ e $\mathrm{g} r o$} \\
\hline & & & \multicolumn{2}{|c|}{ Total } & \multicolumn{2}{|c|}{ Maje } & \multicolumn{2}{|c|}{ Female } & \multicolumn{2}{|c|}{ Total } & \multicolumn{2}{|c|}{ Male } & \multicolumn{2}{|c|}{ Female } \\
\hline & No. & $\begin{array}{l}\text { Per } \\
\text { cent }\end{array}$ & No. & $\begin{array}{l}\text { Per } \\
\text { cent }\end{array}$ & No. & $\begin{array}{l}\text { Per } \\
\text { cent }\end{array}$ & No. & $\begin{array}{l}\text { Per } \\
\text { cent }\end{array}$ & No. & $\begin{array}{l}\text { Per } \\
\text { cent }\end{array}$ & No. & $\begin{array}{l}\text { Per } \\
\text { cent }\end{array}$ & No. & $\begin{array}{l}\text { Per } \\
\text { cent }\end{array}$ \\
\hline Total - - & 214 & 100 & 162 & 100 & 130 & 100 & 32 & 100 & 52 & 100 & 47 & 100 & 5 & 100 \\
\hline $\begin{array}{l}\text { Not registered }--- \\
\text { Registered: }\end{array}$ & 154 & 71.9 & 125 & 77.2 & 98 & 75.4 & 27 & 84.3 & 29 & 55.7 & 25 & 53.2 & 4 & 80.0 \\
\hline Inactive $(a)--$ & 35 & 16.4 & 20 & 12.4 & 15 & 11.5 & 5 & 15.7 & 15 & 28.9 & 14 & 29.8 & 1 & 20.0 \\
\hline Active (b) -- & 25 & 11.7 & 17 & 10.4 & 17 & 13.1 & - & - & 8 & 15.4 & 8 & 17.0 & - & - \\
\hline
\end{tabular}


of'fered by the Kentucky State Employment Service.

\section{Social Service Exchange Registrations}

In the light of the unemployment shown in the backgrounds of the prisoners, 1 it is not surprising to tind that only 31.8 per cent of the cases are not known to one or more of the social agencies in Louisville and Jef'erson county, as is shown in Table 23. page 67. A case was classed as identitied if the Social Service Exchange listed either the prisoner or his parents. Cases of doubtf'ul identification were included in the group "Not Known" to the Exchange. On this basis, 72.3 per cent of the white cases and 55.8 per cent of the Negro cases were identitied.

of those identillied, 22.4 per cent were known to 1 agency, 16.4 per cent to 2 agencies, and 6.5 per cent to 3 agencies; the remaining 22.9 per cent were known to 4 or more agencies, and 6 cases were known to 10 or more agencies. The 83 cases known to 2 or more social agencies represent persistent and difficult problems in the community; they constitute about one third of the entire group of prisoners. A smaller proportion of Negro prisoners were known to social agencies; 44.2 per cent of the Negroes had no registrations as compared to 27.7 per cent for the white prisoners。

\footnotetext{
1 Supra, Table 21, p. 63
} 
TABLE 23

NUMBER OF LOUISVITTE AND JEFFERSON COUNTY SOCIAI AGENCIFS WITH REGISTRATIONS ON PRISONERS BY RACE AND SEX

\begin{tabular}{|c|c|c|c|c|c|c|c|c|c|c|c|c|c|c|}
\hline \multirow{3}{*}{ Number of Agencies } & \multicolumn{2}{|c|}{ Total } & \multicolumn{6}{|c|}{$W h 1 t e$} & \multicolumn{6}{|c|}{$N$ e $g r o$} \\
\hline & & & \multicolumn{2}{|c|}{ Total } & \multicolumn{2}{|c|}{ Male } & \multicolumn{2}{|c|}{ Female } & \multicolumn{2}{|c|}{ Total } & \multicolumn{2}{|c|}{ Male } & \multicolumn{2}{|c|}{ Eema]e } \\
\hline & No. & $\begin{array}{l}\text { Per } \\
\text { cent }\end{array}$ & No. & $\begin{array}{l}\text { Per } \\
\text { cent }\end{array}$ & No. & $\begin{array}{l}\text { Per } \\
\text { cent }\end{array}$ & No. & $\begin{array}{l}\text { Per } \\
\text { cent }\end{array}$ & No. & $\begin{array}{l}\text { Per } \\
\text { cent }\end{array}$ & No. & $\begin{array}{l}\text { Per } \\
\text { cent }\end{array}$ & No. & $\begin{array}{l}\text { Per } \\
\text { cent }\end{array}$ \\
\hline Total - - - & 214 & 100 & 162 & 100 & 130 & 100 & 32 & 100 & 52 & 100 & 47 & 100 & 5 & 100 \\
\hline None - - - - - - & 68 & 31.8 & 45 & 27.7 & 40 & 30.8 & 5 & 15.6 & 23 & 44.2 & 19 & 40.4 & 4 & 80.0 \\
\hline 1 Agency - - - - & 48 & 22.4 & 37 & 22.8 & 31 & 23.8 & 6 & 18.8 & 11 & 21.1 & 11 & 23.4 & - & - \\
\hline 2 Agencies - - - & 35 & 16.4 & 29 & 18.0 & 24 & 18.5 & 5 & 15.6 & 6 & 11.5 & 6 & 12.8 & - & - \\
\hline 3 Agencies - - - & 14 & 6.5 & 12 & 7.4 & 9 & 6.9 & 3 & 9.4 & 2 & 3.9 & 2 & $4 \cdot 3$ & - & - \\
\hline 5 Agencies - - - & 11 & 5.1 & 9 & 5.6 & 6 & 4.6 & 3 & 9.4 & 2 & 3.9 & 1 & 2.1 & 1 & 20.0 \\
\hline 6 to 10 Agencies - & 19 & 8.9 & 14 & 8.7 & 10 & 7.7 & 4 & 12.5 & 5 & 9.6 & 5 & 10.6 & $m$ & - \\
\hline Over 10 Agencies - & 6 & 2.8 & 5 & 3.0 & 4 & 3.1 & 1 & 3.1 & 1 & 1.9 & 1 & 2.1 & - & - \\
\hline
\end{tabular}


CHAPTER VIII

SUMMARY AND CONCLUSIONS

\section{Summary}

The purpose of the study was to determine who is committed to the Louisville Workhouse, the characteristics and composition of the group. The study covered the criminal, social, economic, and personal background of a group of 214 prisoners received at the Workhouse during a two weeks period in March, 1949.

Analysis of the modal groupings of the characteristics of the group studied show that the "typical" prisoner at the Workhouse is a white male, about 37 years old, a native Kentuckian, and a Protestant. He was charged with drunkenness and sentenced to 15 days in the Workhouse. This is his fifteenth commitment. After completing the 8 th grade at the age of 16 , he quit school to go to work. Three years later, at the age of 19, he left home because of the lack of employment opportunities. For at least 5 years, he has lived in the areas in, or adjoining the "Haymarket". He is an unskilled worker, unemployed, but not registered at Kentucky State employment Service. He is either single or in some manner separated from his wife, and has no dependents. He has sought the services of at least two Louisville and Jefiterson County social agencies.

In the latter part of the nineteenth century, drunkenness and disorderly conduct were the principal reasons for commitments. Today's charges are no exception. Drunkenness was the offense in 
42.4 per cent of the commitments studied. When the offenses of disorderly conduct, vagrancy, and loitering are added to the offense of drunkenness, a total of 93.5 per cent of the commitments are accounted for. The average length of sentence for the entire group was 15 days, but the average for the white females was 20 days. For the entire group, 48.2 per cent of the sentences were for 10 days and less. The average fine for the entire group was 舟10.00。

It was found that 59.4 per. cent of the prisoners had been previously committed to the Workhouse. The average number of prior commitments for the group was 14, with the white prisoners having an average of 17 as compared to 6 for the Negro prisoners.

A record of prior arrests was found t'or 87.4 per cent of the group studied. The average number of prior arrests for the white prisoners was almost three times that of the Negro group. The number of prior arrests: for the white females was considerably higher than that of the rest of the group; amounting to 24 , as compared to 12 for the entire group.

The 214 prisoners studied were composed of 75.7 per cent white and 24.3 per cent Negro prisoners. By sex, the prisoners were 82.7 per cent male and 17.3 per cent female. The largest group by race and sex was the 130 white males, amounting to 60.7 per cent of the total prisoners. Negro males totaled 47 , or 22.0 per cent of the entire group. White females numbered 32, or 15.0 per cent, and Negro t'emales 5 , or 2.3 per cent. The average age for the entire group was 37 years, with the males averaging 38 years and the females 33 years. The age of the prisoners, however, ranged from 16 years 
to 70 years.

Most of the prisoners were born in Kentucky, and 60.3 per cent of the parents were also native Kentuckians. Fifty per cent of the prisoners were born in urban areas.

Relatively t'ew, 28 per cent, of the prisoners were married at the time of commitment. About twice as many Negroes as whites were married at the time of arrest; 42 per cent Negro and 23.4 per cent white. Sixty-five per cent of the group had no dependents; for the Negroes 44.2 per cent had no dependents as compared to 71.5 per cent of the white prisoners.

While most of the prisoners had attended school, t'ew of them had completed high sohool. The average age for the group on leaving school was 16, while the average grade completed was the eighth.

The average age on leaving home was 19. "Employment" was the reason given in both instances by the average male prisoner and "marriage" was the reason given by the average t'emale prisoner. Sixty-three per cent of the prisoners had lived in Louisville at least 5 years; while only 24.8 per cent had lived in Louisville less than one year. Those living in Louisville came from low income and deteriorated areas, which includes the "Haymarket" area.

Although the average male prisoner was of draft age and had no obvious physical defects, 60.7 pe $\mathrm{r}$ cent had never served in the Armed Forces. A total of 59 of the 177 male prisoners, or 33.3 per cent, had served in World War II.

While 50.5 per cent of the prisoners gave "employment" as their means of support, 65.4 per cent were unemployed at the time 
of arrest; and 71.9 per cent of the total group were not registered with Kentucky state Employment Service. This would indicate that a larger percentage than 21 per cent who so stated actually had "no visible means of support". A larger percentage of the Negroes than the white prisoners were employed at the time of arrest. of the unemployed prisoners, the Negro group were more inclined to use the services of the Kentucky state Employment Service.

The majority, 86.2 per cent, of the prisoners had been known to one or more social agencies. A smaller proportion of the Negro prisoners were known to social agencies; 44.2 per cent of the Negroes had no registrations as compared to 27.7 per cent of the white prisoners.

\section{Conclusions}

The persons who are committed to the Louisville Workhouse show a variety of economic, social, and personal lacks and handicaps. On the whole, they are poorly educated, lack family ties, are isolated from constructive relationships in the community, are unfitted for earning a living, and show disorganized personality patterns. They are social misfits for whom society is largely content to give the traditional treatment of fines and short sentences. After a brief period in the Workhouse, they return to the community with the same attitudes and personal handicaps and to the same destructive social situations that can only lead to continued non-productive and delinquent lives.

The Department of Public Welfare of the City of Louisville gives humane treatment to these offenders while they are in the 
Workhouse and its officials provide the most constructive program possible within their resources. But the understanding of the citizens of Louisville of the nature of the correctional problem confronting them by the petty offenders in their midst must precede more effective transformation of the methods used in coping with the problem. It is easier f'or the general public to understand and attempt to modify the problems of law entorcement in the community than to analyse and comprehend the problems of postarrest correction involved. Yet, society is protected only it' the system of dealing with misdemeanants results in the rehabilitation or the effective control of those social misfits after arrest. It is hoped that the material presented in this study will contribute to the community understanding of the handicaps and lacks of the segment of the population who are minor of fenders and suggest that the extension of individualized study and treatment will lead to a lessening of the costs of petty delinquencies to the community and to the misdemeanants themselves.

The study has shown the sconomic, personal, and social lacks of the inmates of the Workhouse. It has presented something of the extent of their isolation from constructive forces in the community. The tabulated data also shows signit'icant dif'terences between individuals; each characteristic studied showed a range as well as central tendency. Delinquents are the products of individual personality patterns reacting to specific enviromental fectors. These findings suggest that individualized study and treatment, beginning in the courts and extending through parole supervision following release from the Workhouse, should be applied to the 
problems presented by the misdemeanants. The problems of the misdemeanants are too profound to be treated by fines and short sentences. Social case work services, such as have been introduced in the Workhouse program, need to be made the keystone of the correctional treatment of misdemeanants. The aid of modern scientitic techniques in the practices of law, medicine, psychiatry, and psychology should be called into operation to greater degrees. The goal of correctional treatment should be not only to save the community the direct consequences of delinquent acts but also to permit the of'enders to make positive contributions to society.

Misdemeanants are born in and nurtured by the society that paradoxically, first creates them and then measures their behavior against set standards of right and wrong. It is true that the very continuation of an organized society requires that the members thereof be held responsible for the consequences of their acts. Perhaps the paradox is relieved it organized society holds itself responsible to provide the most modern and scientific aids and techniques to the individually responsible misdemeanant so that he will be helped, encouraged, and stimulated to solve his difficulties.

This study has analysed a representative group of persons committed to the Louisville Workhouse and has shown a measure of the composition of the group, who they are in a collective sense. Another study should follow to show the detailed causative factors operating to produce the delinquent behavior, why they commit offenses. The complex of causation can probably be studied best 
through a series of intensive case histories. Hinally, a third study, based on the findings of the first two surveys, should be made to determine the elements of the soundest program of correction and control to apply to apprehended misclemeanants. The interest of the personnel of the City Department of Public Welfare that such studies be made provides a hopetul omen that the community is ready to face squarely and deal with the difficult problem of the correctional treatment of the misdemeanant. 
POWERS AND DUTIES OF IHE DEPARIMENI OF PUBLIC

WELFARE, LOUISVILLH, KENTUCKY

"The Department of Public Welfare of" cities of the first class shall be under the supervision and direction of a director to be designated director of welfare, and shall, except as otherwise provided by law, have exclusive control, under the Acts of the General Assembly and the ordinance of the legislative body of siad cities, of all matters relating to the provision for and the supervision of the care of adult and juvenile delinquents, dependents, and persons mentally deficient; the investigation of conditions that develop dependency, delinquency and mental deficience; the education of the public regarding such conditions and the adoption of remedial measures; the supervision of public baths, comfort stations and cemeteries, (the Detention Home,) the Home for the Aged and Infirm, the City Workhouse; and may prescribe rules and regulations for the government and discipline of the inmates of the city's charitable and penal institutions including in such rules general provisions for the deduction, for good conduct, from the time of persons confined in such penal institutions by reason of a judgment of the police court of said city; and the supervision of the maintenance at the University of Louisville of classes in social welfare in order to provide trained workers for service in said department; and such other matters as may by ordinance be placed under the control of the sei d department not in conflict with any Act of the General Assembly. The Director of welfare shall have the power to organize the said department for administrative purposes into such divisions as may be necessary for the proper conduct of the busines's of said department, and to appoint heads or chief's of such divisions who, under the supervision of said director, shall have the direction of such divisions."

${ }^{2}$ City of Louisville, ordinance 98.010 (2862) "Department of Public Welfare; Powers; Duties," January 1, 1930. 


\author{
APPENDIX B \\ LETTER DATED JULY 30, 1948, FROM MISS LOUISE DIECKS, \\ DIRECTOR, LOUISVILLE DEPARTMENT OF WELFARH
}

Dean Howell V. Williams

Kent School of Social Work

University of Louisville

Louisville 8, Kentucky

Dear Dean Williams:

In regard to your "Announcement of Research Program," there is one subject that I should like for you to take into consideration and that is a study of the kinds of people who become the responsibility ot an institution such as the Louisville City Workhouse. I think that the scientitic treatment of such persons is something that will develop in the not too distant I'uture. The treatment of such persons is largely an unexplored tield and one which communities will be obliged to face and do something about.

I believe that a study by Kent School students of the types of people who find their way into the City Workhouse, their problems, their background, and the apparent causes which bring them into the institution, would be very valuable to the Welfare Department and to the community.

LD:sls

\author{
Sincerely yours, \\ Louise Diecks (signed) \\ Louise Diecks \\ Director of Welfare
}




\section{APPENDIX C}

WUMBER OF PRISONERS LIVING IN LOUISVILLE, BY CENSUS TRACT

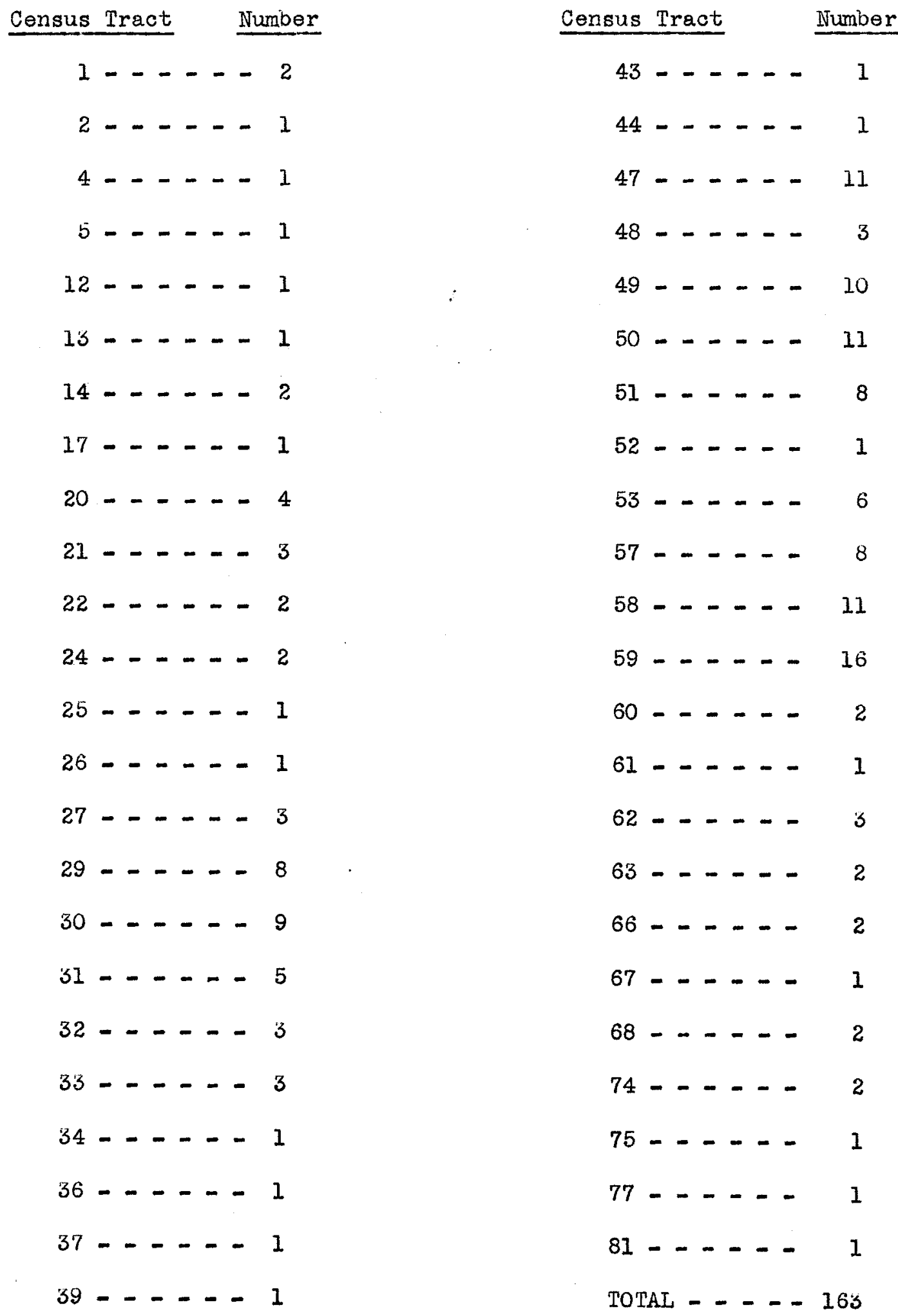




\section{APPENDIX D}

NUMBER OF PRISONERS BORN IN KENTUCKY, BY COUNTY

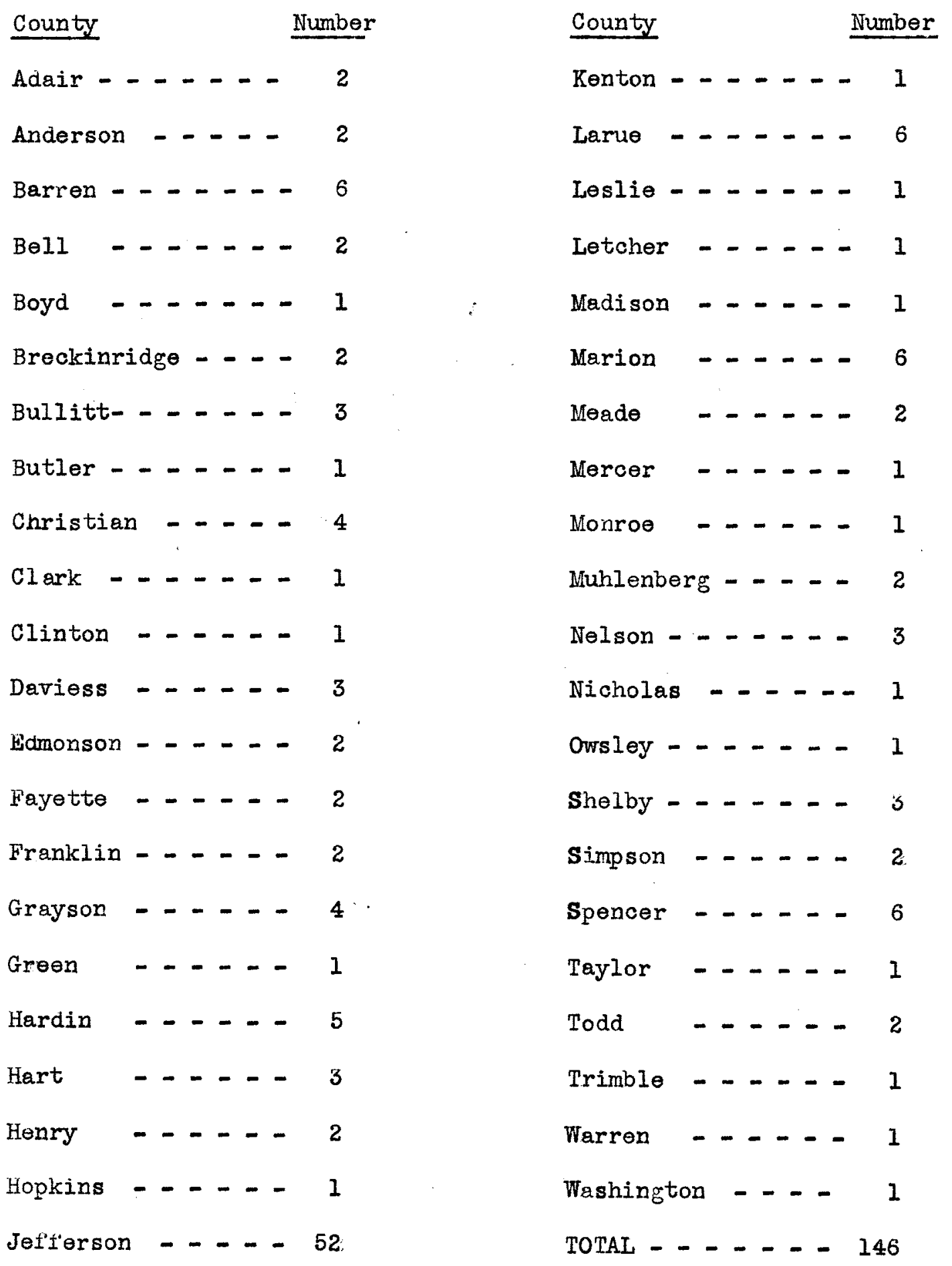


DAPLi

1. Name

2. Sex

3. Nearest of kin

4. Address

6. W CoI other

8. Grade quit School

10. How long in Louisville

12. Name of last employer

13. Obvious Physical detects

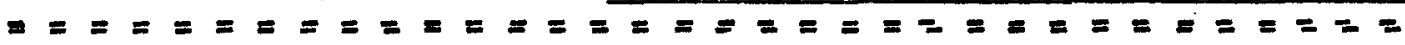

14. Place and date of birth

15. Age left home

Reason

16. Previous addresses

17. Birthplace of Mother Father

18. Dependents

19. Means of support 20. Trade

21. Date of last regular employment Type

22. Remarks

25. Present oftense

24. Sentence

25. Past Arrests

26. Previous Commitments to Workhouse

27. Date of expiration of sentence

28. Previous Commitments

29. K.S.HE.S. date of last reg. Length job held

30. S.S.X. Initials 


\section{BIBLIOGRAPHY}

Department of Public Welfare, Annual Report Fiscal Year June 30, 1945 to July I, 1946 Louisville, Kentucky.

Department of Public Welfare, Annual Report Fiscal Year June 30 , 1944 to July 1,1945 Louisville, Kentucky.

Department of Public Welfare, Annual Report Fiscal Year June 30 , 1941 to July 1, 1942 Louisville, Kentucky.

Department of Public Welfare, Annual Report Fiscal Year June 30 , 1937 to July 1, 1938 Louisville, Kentucky.

Department of Public Welfare, Annual Report Fiscal Year June 30 , 1936 to July 1, 1937 Louisville, Kentucky.

Department of Public Welfare, Annual Report Fiscal Year June 30 , 1933 to July 1, 1934 Louisville, Kentucky.

Department of Public Welfare, Annual Report Fiscal Year June 30 , 1931 to July 1, 1932 Louisville, Kentucky.

Barnes and Teeters, New Horizons in Criminology. Prentiss Hall Co., 1947.

Crumley, James J., "The Workhouse Prisoner a Problem in Social Treatment". Unpublished Report, Department of Welf'are, Louisville, Kentucky, 1941.

Federal Relief Project, "History of the City Workhouse". Unpublished Report, Department of Welfare, Louisvilie, Kentucky, 1931.

"Jails and Workhouse". A Report Prepared by Sub-Committee of Workhouse Welfare Committee, Louisville Area Development Association, Louisville, Kentucky; June 29, 1944. (mimeographed).

Prison Industries Reorganization Administration. The Prison Problem in the District of Columbia. Washington; Government Printing office, 1938.

Reiger, Charles J. Jr., "The Louisville City Workhouse". Unpublished Paper, Department of Sociology, University of Louisville, 1937.

Thompson, Eugene T., "City Workhouse Population of Male Prisoners". Unpublished Report, Department of Welfare, Louisville, Kentucky. June, 1948. 